PIOTR BILIŃSKI

Instytut Studiów Międzykulturowych

Uniwersytetu Jagiellońskiego

\title{
DZIAŁALNOŚĆ WŁADYSŁAWA KONOPCZYŃSKIEGO W POLSKIM TOWARZYSTWIE HISTORYCZNYM (1913-1939)
}

\begin{abstract}
Abstrakt: Autor niniejszego tekstu skoncentrował się na działalności Władysława Konopczyńskiego w Polskim Towarzystwie Historycznym w okresie dwudziestolecia międzywojennego. Przez cały ten okres uczony był spiritus movens tej organizacji. Potrafił tchnąć życie w skostniały krakowski oddział PTH i zainspirować członków do zbiorowych wysiłków badawczych.

Słowa kluczowe: historia historiografii, historiografia polska w okresie dwudziestolecia międzywojennego, Polskie Towarzystwo Historyczne, „Kwartalnik Historyczny”, Władysław Konopczyński.
\end{abstract}

Abstract: The author focused on the activity of Władysław Konopczyński for the Polish Historical Society in the interwar years. The scholar was the "spiritus movens" of the Society throughout the whole period. He was able to breathe new life into the fossilized Cracow branch of the PHS and inspire its members to a collective research effort.

Keywords: history of historiography, Polish historiography in the interwar period, Polish Historical Society, Kwartalnik Historyczny (The Historical Quarterly), Władysław Konopczyński.

Celem niniejszego artykułu jest przybliżenie na przykładzie działalności Władysława Konopczyńskiego w Polskim Towarzystwie Historycznym pewnych elementów funkcjonowania środowiska historycznego w okresie dwudziestolecia międzywojennego. Podstawą źródłową ustaleń jest obejmujący lata 1895-1952 dziennik uczonego, który znajduje się w prywatnym archiwum Rodziny Konopczyńskich w Warszawie. Obejmuje on około 7 tys. stron tekstu w formacie $10 \times 16 \mathrm{~cm}$. Zawiera przed wszystkim (ok. 90 proc.) informacje dotyczące życia rodzinnego historyka i zarządu majątku w Młyniku. Resztę zapisków wypełnia praca naukowo-dydaktyczna, działalność polityczna i społeczna. Dziennik jest pisany w formie 
lakonicznych zdań i niezwykle rzadko zawiera odautorskie oceny. Wypisy dzienne liczące od 15 do 20 wierszy zajmują zazwyczaj pół strony. Zapiski często powstawały z pewnym opóźnieniem, nawet miesięcznym, przez co niekiedy zawierają błędy i nieścisłości dotyczące dat opisywanych zdarzeń. Każdy zapis zaczyna się od podania dnia tygodnia i daty dziennej. Oprócz dzienników, w pracy wykorzystano materiały rozproszone w różnych krajowych i zagranicznych archiwach i bibliotekach, m.in. Archiwum Uniwersytetu Jagiellońskiego, Archiwum Nauki PAN i PAU w Krakowie, Archiwum PAN w Warszawie, Biblioteki Jagiellońskiej, Biblioteki Zakładu Narodowego im. Ossolińskich we Wrocławiu, artykuły wspomnieniowe i pamiętnikarskie, a także literaturę przedmiotu.

Konopczyński, od 1907 r. członek lwowskiego Towarzystwa Historycznego i warszawskiego Towarzystwa Miłośników Historii, pragnął, aby podobna organizacja powstała w Krakowie $^{1}$. Na pomysł założenia filii Towarzystwa Historycznego wpadł w lutym 1911 r. Marian Łodyński, który zaraził swoim pomysłem Konopczyńskiego². Ten z kolei przekonał do założenia koła Towarzystwa Historycznego sekretarza generalnego Akademii Umiejętności Bolesława Ulanowskiego ${ }^{3}$. Po tych wstępnych konsultacjach, z powodu wyjazdu Konopczyńskiego na zagraniczną kwerendę naukową, sprawa utknęła w martwym punkcie na półtora roku. Do tematu powrócono w październiku 1912 r. Konopczyński próbował wtedy

1 Zmiana nazwy z Towarzystwo Historyczne na Polskie Towarzystwo Historyczne miała miejsce w 1924 r. Dzieje PTH posiadają już bogatą literaturę, zob. m.in. E. Barwiński, Towarzystwo Historyczne 1901-1914, KH 51, 1937, 1-2, s. 19-40; T.E. Modelski, Towarzystwo Historyczne 1914-1924, KH 51, 1937, 1-2, s. 41-88; K. Tyszkowski, Polskie Towarzystwo Historyczne 1925-1936, KH 51, 1937, 1-2, s. 89-137; F. Papée, Słowo wstępne, KH 53, 1939, 1, s. 194-196; J. Feldman, Ćwierćwiecze działalności krakowskiego Oddziału Polskiego Towarzystwa Historycznego, KH 53, 1939, 1, s. 196-203; J. Garbacik, Oddział krakowski (1913-1956), w: Polskie Towarzystwo Historyczne, 1886-1956. Księga pamiatkowa z okazji zjazdu jubileuszowego Polskiego Towarzystwa Historycznego w Warszawie 19-21 X 1956 roku, red. S. Herbst, I. Pietrzak-Pawłowska, Warszawa 1958, s. 193-200; M. Frančić, Polskie Towarzystwo Historyczne w Krakowie w latach 1913-1939, w: Polskie Towarzystwo Historyczne 1886-1986. Zbiór studiów i materiałów, red. S.K. Kuczyński, Wrocław 1990, s. 97-110; T. Kondracki, Polskie Towarzystwo Historyczne w latach 1918-1939, Torun 2006 (zdecydowanie najwartościowsza praca na temat PTH); T.P. Rutkowski, Polskie Towarzystwo Historyczne w latach 1945-1958. Zarys dziejów, Toruń 2009; P. Sierżęga, Kazimierz Tyszkowski (1894-1940). Z dziejów nauki polskiej w międzywojennym Lwowie, Rzeszów 2011, s. 172-213; B. Tracz, Krakowski Oddział Polskiego Towarzystwa Historycznego i jego członkowie 1913-1945, Kraków 2013.

2 Archiwum Rodziny Konopczyńskich w Warszawie, W. Konopczyński, „Dziennik”, z. 49-136, rkps, s.nlb. (dalej: W. Konopczyński, „Dziennik”); tu z. 49, zapis z 8 II 1911. Część zapisków niedawno ukazała się drukiem, por. W. Konopczyński, Dziennik 1918-1921, cz. 1-2, wstęp P. Biliński, P. Plichta, Warszawa-Kraków 2016.

3 W. Konopczyński, „Dziennik”, z. 49, zapis z 28 II 1911. 
przekonać do pomysłu Łodyńskiego Stanisława Kutrzebę i Wacława Sobieskiego, ale żaden nie wykazał nim zainteresowania ${ }^{4}$. Zrezygnowany, zaczął tracić nadzieję na utworzenie w Krakowie Towarzystwa Historycznego: „Straszna oziębłość wzajemna tutejszych historyków” konstatował ze smutkiem ${ }^{5}$, dodając że ,jeżeli nadal tyle będzie oziębłości, trzeba będzie zamknąć się w domu jak inni i nie kompromitować swej inicjatywy"6.

Sprawę przesądziła grudniowa rozmowa z dyrektorem Biblioteki Jagiellońskiej i współzałożycielem Towarzystwa Historycznego we Lwowie, Fryderykiem Papée, którego Konopczyński zachęcił do założenia krakowskiego koła Towarzystwa Historycznego i użyczenia mu lokalu w Collegium Maius ${ }^{7}$. Od tego momentu rozpoczęła się krzątanina wokół planowanego Towarzystwa. Jednak autor Polski w dobie wojny siedmioletniej nie widział „innych chętnych ludzi do pracy oprócz Papéego, Łodyńskiego, no i [Stanisława] Zachorowskiego"'.

Rozmowy z profesorami, którzy mieszkali w tej samej kamienicy co Konopczyński - Józefem Tretiakiem, Marianem Zdziechowskim i Franciszkiem Fuchsem - nie przyniosły efektów. Natomiast próba skłonienia Stanisława Krzyżanowskiego do zorganizowania konferencji 16 historyków w celu założenia filii Towarzystwa Historycznego zakończyła się powodzeniem. Konopczyński nie był szczęśliwy, że „fatalnie dał się wykierować na inicjatora tego przedsięwzięcia”, ale na początku grudnia 1912 r. miał już zaplanowanych na następne pół roku sześć odczytów. Zastanawiał się, „kto [z wykładowców] ściągnie słuchaczy, kto pootwiera im usta do dyskusji"9. Po konsultacji z Krzyżanowskim ustalił termin konferencji historyków na 14 grudnia $1912 \mathrm{r}^{10}{ }^{10}$ Dzień ten okazał się bardzo ważny w życiu krakowskiego środowiska historycznego, wtedy bowiem powstał komitet wykonawczy, który postawił sobie zadanie stworzenia osobnego koła Towarzystwa Historycznego, „opracowanie organizacji i stosunku do Lwowa". W spotkaniu wzięło udział 18 badaczy; obok Konopczyńskiego byli to: Franciszek Bujak, Edmund Długopolski, Franciszek Duda, ks. Jan Fijałek, Roman Grodecki, Kazimierz Kaczmarczyk, Abdon Kłodziński, Ludwik Kolankowski, Stanisław Krzyżanowski, Marian Łodyński, Kazimierz Marian Morawski, Fryderyk Papée, Jan Ptaśnik,

\footnotetext{
${ }^{4}$ Ibidem, z. 54, zapis z 5 X 1912.

5 Ibidem, zapis z 10 XI 1912.

${ }^{6}$ Ibidem, zapis z 15 XI 1912.

7 Ibidem, z. 55, zapis z 4 XII 1912.

8 Ibidem, zapis z 7 XII 1912.

9 Ibidem, zapis z 9 XII 1912.

10 Ibidem, zapis z 10 XII 1912.
} 
Wacław Sobieski, Wacław Tokarz, Józef Tretiak i Stanisław Zachorowski. Po krótkim wprowadzeniu głos zabrał Konopczyński, który „wyłuszczył całą rzecz". Na przewodniczącego komitetu powołano Papéego, członkami zostali Sobieski, Tokarz, Łodyński i Konopczyński1"

Dwa dni później odbyło się pierwsze posiedzenie komitetu wykonawczego, na którym „Tokarz świecił nieobecnością, Sobieski odznaczał się jak zwykle nonszalancją i cygańskim stylem"12. Papée ułożył listę blisko 100 członków, uczony dodał do niej jeszcze kilkanaście nazwisk, tak że razem zebrano ponad 120 historyków. Konopczyński, będący spiritus movens całego przedsięwzięcia, udał się do Tokarza, aby go prosić o objęcie wiceprezesury koła. Ten jednak odmówił ${ }^{13}$. W tej sytuacji zastukał do drzwi sekretarza generalnego AU Ulanowskiego, lecz podjęta dwukrotnie próba pozyskania jego wsparcia także zakończyła się fiaskiem, głównie z powodu fizycznej niedyspozycji profesora. Nie było bowiem „tajemnicą dla nikogo, że Ulanowski choruje na alkoholizm" - konstatował w dzienniku Konopczyński ${ }^{14}$. Następne kroki skierował do Stanisława Smolki, ale i ten odmówił współudziału. Wobec inercji starszej profesury młody uczony doszedł do przekonania, że nowo powstałe koło „obejdzie się bez dygnitarzy"15.

Niewątpliwie tworzenie nowej organizacji spotykało się z oporem ze strony „starych”, którzy uważali Komisję Historyczną Akademii Umiejętności za wystarczający organ dla rozwoju pracy naukowej. Podobne odczucia miał Papée, który we wspomnieniach odnotował, że krakowskim profesorom „nasuwały się zrazu wątpliwości: «po co wnosić sowy do Aten», po co tworzyć jeszcze jedno kółko kulturalne, gdy ich już było tyle w Krakowie"16. Po latach Józef Feldman, oceniający postawy z okresu tworzenia krakowskiego koła Towarzystwa, przyznawał, że w podwawelskim grodzie „nie odczuwano potrzeby tworzenia nowej placówki. Wydawało się, że na wypełnienie jej świeżą treścią braknie siły i czasu"17.

11 stycznia 1913 r. na Uniwersytecie Jagiellońskim odbyło się spotkanie organizacyjne, na którym zebrani historycy jednogłośnie powołali do życia krakowskie koło Towarzystwa Historycznego ${ }^{18}$. Jak wspominał Konopczyński:

\footnotetext{
11 Ibidem, zapis z 14 XII 1912.

12 Ibidem, zapis z 16 XII 1912.

13 Ibidem, zapis z 17 XII 1912.

14 Ibidem, zapis z 2 I 1913.

15 Ibidem, zapis z 10 I 1913.

16 F. Papée, op. cit., s. 195.

17 J. Feldman, op. cit., s. 197.

18 B. Tracz, op. cit., s. 15-16.
} 
przyszedłem do sali XXXV już o 6-ej, gdy było coś 10-12 osób obecnych. Stopniowo zeszło się około 75, dużo nieznajomych twarzy; nauczycieli gimnazjalnych. Parę osób przybyło aż z prowincji [--]. Szło z początku gładko niby konwokacja Czartoryskich. De improviso dali się zaprosić do komitetu redakcyjnego Fijałek, Sobieski, [Michał] Rostworowski; Fuchs zgodził się wejść do zarządu. Oracja Papéego trochę zbyt może patetyczna (z początku miał straszną tremę); ja mówiłem płynnie, wyraziście ściągając z kartki; Łodyński może zbyt rozciągle o „Kwartalniku” [Historycznym] (ale dobrze). Potem też de improviso - utknęliśmy na haku autonomii finansowej, którą zakwestionowali pod względem prawnym [Antoni] Karbowiak i Krzyżanowski; wypadło zrobić jeszcze parę poprawek, a kwestię pieniężną zupełnie skreślić. Obrano do zarządu Papéego, Tokarza, mnie, Łodyńskiego i Fuchsa. Nie najgorzej poszło i nie najlepiej ${ }^{19}$.

Po uroczystej inauguracji, Konopczyński zabrał się do sporządzenia regulaminu koła, który zamierzał wysłać do prezesa TH Tadeusza Wojciechowskiego we Lwowie ${ }^{20}$. Przy układaniu tekstu wspierał go radą Karbowiak, o którym w dzienniku pisał, że „to człek z ogniem, dodający animuszu" ${ }^{21}$. Gotowy projekt historyk zaniósł Papéemu, który z kolei oddał go do przejrzenia Krzyżanowskiemu ${ }^{22}$. Kilka dni później doszło do spotkania Papéego, Krzyżanowskiego, Łodyńskiego i Konopczyńskiego, podczas którego zredagowano ostateczny projekt regulaminu. Papéego udało się skłonić do zwołania pierwszego zebrania odczytowego, które odbyło się 26 stycznia 1913 r. Wykład o „Tajemnicy Trembeckiego” wygłosił, w obecności około czterdzieściorga słuchaczy, Konopczyński²3. Jednak oficjalna inauguracja odbyła się kilka dni później. Uświetnił ją odczyt Papéego pt. „Przegląd dziejów Władysława Jagiellończyka 1434-1444”. Konopczyński notował: „zebranie odbyło się w komplecie coś 51-52 osób. Przewodniczył Tokarz, ja sekretarzowałem. Odczyt Papéego treściwy, niezły, ale przydługi. Poza tym zbyt ciężko gadał Fijałek, zbyt długo Korzeniowski, inni krócej. Tokarz był wściekły, że sprawa przeciągnęła się poza godzinę ósmą"24.

W momencie wybuchu wojny działalność krakowskiego koła Towarzystwa Historycznego została przerwana na dwa lata. W tym czasie Konopczyński wraz z rodziną przebywał w Szwecji i Danii. Po powrocie do Krakowa natychmiast włączył się w działalność koła, ale nie był

\footnotetext{
19 W. Konopczyński, „Dziennik”, z. 55, zapis z 11 I 1913.

${ }^{20}$ Ibidem, zapis z 16 I 1913.

${ }^{21}$ Ibidem, zapis z 22 I 1913.

22 Ibidem, zapis z 23 I 1913.

${ }^{23}$ Ibidem, zapis z 28 I 1913.

${ }^{24}$ Ibidem, zapis z 1 II 1913.
} 
zachwycony jego poczynaniami. 19 lutego 1916 r. uczestniczył w posiedzeniu, podczas którego „obrano dawny zarząd, dawny komitet «redakcyjny», ale cóż z tego, kiedy nikt pracować nie myśli, mało kto płaci składki, ze Lwowem trudno się skomunikować"25.

Po odzyskaniu przez Polskę niepodległości, przed Konopczyńskim, członkami Towarzystwa Historycznego i badaczami innych dyscyplin naukowych stanął problem przedyskutowania najważniejszych problemów wynikłych z nowej sytuacji politycznej. Służyć miał temu ogólnopolski zjazd poświęcony zagadnieniom organizacji nauki, planowany na kwiecień 1920 r. Organizatorem przedsięwzięcia była Kasa im. Józefa Mianowskiego. Profesor obawiał się zmarginalizowania krakowskiego środowiska historycznego przez prężnie rozwijający się pod kierunkiem Marcelego Handelsmana ośrodek warszawski. Nastrojom tym dawał wyraz w liście do Bujaka:

Coś tam robią w Akademii, ale obawiam się, że nie dosyć. Nie widzę tego zapału, rozpędu, który jedynie potrafiłby utrzymać pierwszeństwo Akademii wobec tendencji hegemonistycznych Warszawy. W szczególności na terenie nauk historycznych powinien by Kraków mocno bronić swego stanowiska. Chodzi o to, kto dostanie (zorganizuje) Instytut Historyczny. Wiem, że dąży do tego Warszawa (Handelsman). Byłaby to dla Krakowa, Akademii, Uniwersytetu Jagiellońskiego klęska. Ale co począć na tutejszy zastój akademicki, owoc gospodarki ludzi zużytych. Nie wiem, jakiego ty jesteś zdania o Instytucie i o kwalifikacjach naukowych Warszawy, ale ja sądzę, że pomijając inne względy, powinno się dbać o decentralizację kultury. Handelsman pisał do [Ludwika] Finkla, że warszawiacy chcą zwołać IV Zjazd Historyków Polskich do Warszawy już na rok przyszły. Tutaj przyjeżdżał z podobną propozycją Dembiński. Opinia zgodna Krakowa i Lwowa: zjazd w przyszłym roku niemożliwy (za późno, za drogo etc.). Ale konieczna konferencja delegatów różnych instytucji (towarzystw, komisji, może i uniwersytetów) w sprawie organizacji nauki historycznej. Taka konferencja podzieli pracę, zatwierdzi programy, obmyśli w ogólnych liniach zużycie funduszów itd. Może ona odbyć się już na wiosnę. Lepiej w Krakowie (bo taniej) niż w Warszawie. Ten pogląd przesłałem Handelsmanowi. Odpowiedzi dotąd nie mam. Jeżeli go podzielasz, to agituj przy sposobności w naszym duchu ${ }^{26}$.

W obliczu narastających problemów polskiej historiografii zaakceptowano przedłożoną przez Konopczyńskiego propozycję zwołania konferencji organizacyjnej. Jako miejsce wybrano Warszawę, gdzie w kwietniu

25 Ibidem, z. 66, zapis z 19 II 1916.

${ }^{26}$ BO, Przyb. 120/58, rkps, k. 141-144; List W. Konopczyńskiego do F. Bujaka, Kraków, 14 XII 1919, cyt. za: T. Kondracki, Polskie Towarzystwo Historyczne, s. 31-32. 
1920 r. miał obradować wspomniany zjazd poświęcony nauce polskiej. Uznano, że po jego zakończeniu historycy będą mogli pozostać w stolicy jeszcze dwa dni i omówić w sposób mniej formalny interesujące ich kwestie. Oczekiwana konferencja w sprawie organizacji nauki historycznej rozpoczęła się 11 kwietnia 1920 r. w kamienicy TMH przy Starym Rynku w Warszawie. Obradom przewodniczył nestor lwowskich historyków prawa, Władysław Abraham. W spotkaniu wzięło udział 50 historyków, w tym 30 delegatów różnych instytucji. Podstawę do szerszej dyskusji przyniósł odczyt Konopczyńskiego pt. „Ogólna organizacja badań historycznych w Polsce”. W swoim wystąpieniu uczony dużo miejsca poświęcił Towarzystwu Historycznemu, zwracając szczególną uwagę na jego organizację i zadania, jakie przed nim stały. Uważał, że główną sferą działalności tej instytucji powinna być praca naukowa oparta na krytycznie zanalizowanych źródłach. Ponadto, wychodząc z założenia szkodliwości konkurencji między towarzystwami naukowymi, poddał pod głosowanie wniosek, aby Konferencja Organizacyjna Historyków Polskich wyraziła przekonanie, że w „Zjednoczonej Polsce powinno istnieć tylko jedno ogólne Towarzystwo Historyczne z zarządem we Lwowie, a z miejscowymi kołami autonomicznymi (na wzór krakowskiego) w Warszawie, Poznaniu, Lublinie itd." ${ }^{27}$. Wniosek ten poparł Władysław Semkowicz, który widział potrzebę pozostawienia Lwowa jako siedziby ogólnopolskiego towarzystwa ${ }^{28}$. W odpowiedzi na to wystąpił Handelsman, optujący za tym, by powstały różne „polskie towarzystwa historyczne ogólne i specjalne", a nie jedno z lwowską centralą. Po dłuższej dyskusji odbyło się głosowanie, w którym za wnioskiem Konopczyńskiego opowiedziało się 23 historyków, przeciw byli tylko Handelsman i Stanisław Kętrzyński. Kutrzeba zaproponował utworzenie w Krakowie Instytutu Historycznego „dla podejmowania wszelkich zamierzeń wydawniczych", dodając, że najlepszym rozwiązaniem byłoby utworzenie tego instytutu przy Komisji Historycznej Polskiej Akademii Umiejętności ${ }^{29}$. Wniosek przyjęto jednomyślnie. Po głosowaniu Konopczyński zwracał uwage na konieczność inwentaryzowania źródeł, zaproponował opracowanie podręcznika „o archiwach oraz repertorium aktów do dziejów dyplomacji i wojskowości"30. I ten wniosek został jednogłośnie przyjęty.

${ }^{27}$ Konferencja $w$ sprawie organizacji nauki historycznej w Polsce, PH 22, 1919-1920, s. 305. Szerzej zob. T. Kondracki, Polskie Towarzystwo Historyczne, s. 34-37; B. Tracz, op. cit., s. 29-31.

${ }^{28}$ J. Semkowiczowa, „Życie i działalność prof. UJ Władysława Semkowicza”, BJ, 9621 III, rkps, k. 147.

${ }^{29}$ Konferencja $w$ sprawie organizacji..., s. 305.

30 Ibidem, s. 306. 
Uczony był zadowolony z przebiegu obrad, przyznając, że uczestnicy stanęli na wysokości zdania ${ }^{31}$.

W drugim dniu konferencji Konopczyński wystąpił z dwoma referatami: „Stosunek do nauki zagranicznej” i „Typy czasopism i wydawnictw”. W dyskusji postulował nadto „założenie naukowego biura tłumaczeń, które by według poleceń naszych organizacji historycznych dokonywało przekładu wartościowych dzieł i artykułów na języki obce"32. W kolejnym wniosku kładł nacisk na stworzenie mocnych podstaw finansowych „Kwartalnika Historycznego” i „Przeglądu Historycznego” przez zapewnienie im subwencji rządowej33. Oba wnioski przyjęto jednomyślnie. Podsumowując dwudniowy kongres, profesor z zadowoleniem stwierdzał, że panował na nim „,ton bardzo poważny, a przemówienia były wszystkie do rzeczy. Zewnętrzna organizacja bardzo dobra" ${ }^{34}$. W praktyce większość zgłoszonych wniosków pozostała na papierze. Głównym powodem tej stagnacji był brak organu wykonawczego na kształt powołanej w $1925 \mathrm{r}$. Stałej Delegacji Zjazdów Historyków Polskich. Jednak Konopczyński nie ustawał w wysiłkach, aby to, co uchwalono, wcielić w życie ${ }^{35}$.

W roku 1925 doszło do reorganizacji Towarzystwa; uchwalono nowy statut, powołano centralę z siedzibą we Lwowie i podporządkowano jej pięć oddziałów - w Warszawie, Krakowie, Poznaniu, Wilnie i Lwowie ${ }^{36}$. Podczas Walnego Zgromadzenia Delegatów, 20 lutego 1925 r., Konopczyński jako nowo wybrany wiceprezes przeciwstawił się ustaleniom faworyzującym warszawskie $\mathrm{TMH}^{37}$. Swoje obiekcje uzasadnił podczas posiedzenia Zarządu Głównego $\mathrm{PTH}^{38}$. W tajnym głosowaniu wniosek Konopczyńskiego nie przeszedł. Jak wspominał w dzienniku, nie poparł go nikt z członków zarządu ${ }^{39}$. Natomiast w Krakowie uczony „uzyskał zupełny aplauz w sprawie stosunku do Warszawy i Handelsmana"40. W rękopiśmiennej spuściźnie Konopczyńskiego zachował się egzemplarz postanowień umowy PTH z TMH. Jak wynika z jego treści, główną

31 W. Konopczyński, „Dziennik”, z. 77, zapis z 11 IV 1920.

32 Konferencja w sprawie organizacji..., s. 308.

33 Ibidem, s. 310.

34 W. Konopczyński, „Dziennik”, z. 77, zapis z 12 IV 1920.

35 Szerzej zob. T. Kondracki, Polskie Towarzystwo Historyczne, s. 30-43. Zob. też idem, Z myślą o przeszłości polskiej nauki historycznej (konferencja warszawska 11-12 IV 1920 r.), „Teki Historyczne" 21, 1994-1995, s. 141-151.

${ }^{36}$ Szerzej zob. B. Tracz, op. cit., s. 37-42.

37 Archiwum Polskiej Akademii Nauk w Warszawie (dalej: APAN), PTH I-3, j.a. 3, Protokół Walnego Zgromadzenia Delegatów PTH, Lwów, 20 II 1925.

${ }^{38}$ Ibidem, Protokół z posiedzenia Zarządu Głównego PTH, Lwów, 21 II 1925.

39 W. Konopczyński, „Dziennik”, z. 93, zapis z 21 II 1925.

${ }^{40}$ Ibidem, zapis z 6 III 1925. 
niechęć profesora budziło powierzenie historykowi ze stolicy (tj. Handelsmanowi) reprezentacji Towarzystwa wobec zagranicy ${ }^{41}$. Ponadto irytował go zapis gwarantujący Warszawie jedną z trzech wiceprezesur Towarzystwa ${ }^{42}$.

W zimie 1925 r. wśród młodych historyków, którym przewodził Józef Feldman, zrodził się pomysł odsunięcia od kierownictwa Papéego i zastąpienia go ruchliwszym prezesem. Konopczyński wspominał, że o zawiązanym „pakcie” wiele opowiadał mu Feldman ${ }^{43}$. Rok później, nie mogąc pogodzić się z zaistniałą sytuacją, młodzi badacze zamierzali bojkotować Walne Zgromadzenie krakowskiego oddziału ${ }^{44}$. Napięta sytuacja spowodowała, że Papée podał się do dymisji, a jego miejsce zajął Sobieski ${ }^{45}$.

W 1927 r. Konopczyński zaproponował utworzenie Sekcji Krytycznej krakowskiego oddziału PTH, która opiniowałaby ważniejsze publikacje i dbała o wysoki poziom merytoryczny recenzji w „Kwartalniku Historycznym” ${ }^{46}$. Profesor uważał, że „tą drogą uda się 1. Zachęcić do pisania recenzentów starszych. 2. Lepiej wyszkolić młodych". Zabiegał też o pomoc Ptaśnika, którego prosił o „1. egzemplarze recenzyjne. 2. Honoraria nieco wyższe niż za rozprawy i miscellanea. 3. Punktualność $\mathrm{w}$ jego wypłacie. 4. Umieszczanie w «Kwartalniku» polecanych przez tutejszą sekcję recenzji z takim zaufaniem, jak gdyby zostały one zakwalifikowane przez samego Naczelnego Redaktora" ${ }^{47}$. Profesor zamierzał pokierować Sekcją Krytyczną wraz z Feldmanem, którego bardzo cenił jako recenzenta prac historycznych ${ }^{48}$. Jej komitet przewodzący został

41 „Zamierzam obstawać [--], żeby zaprotestować przeciw oddaniu raz na zawsze w statucie przedstawicielstwa historyków wobec zagranicy Warszawie. To jest możliwe tylko od czasu do czasu, z roku na rok, sposobem mandatu od Zarządu Głównego, a nie w formie statutowej”, BO, Przyb. 120/58, rkps, List W. Konopczyńskiego do F. Bujaka, Kraków, 11 XII 1924, s. nlb.; „Piszę o tym Zakrzewskiemu, ale akcentując zarazem, że cały Kraków przeciwny jest odstępowaniu «Warszawie» raz na zawsze przedstawicielstwa na zewnątrz, proszę o odwleczenie tej sprawy, bo sami warszawiacy przecież zrozumieją niesłuszność tej pretensji. [--] Tutaj pan Handelsman jest wszędzie i wszystkim”, ibidem, List W. Konopczyńskiego do F. Bujaka, Kraków, 5 IV 1925.

${ }^{42}$ BJ, Przyb. 142/61, rkps. Szerzej zob. T. Kondracki, Polskie Towarzystwo Historyczne, S. $80-81$.

${ }^{43}$ W. Konopczyński, „Dziennik”, z. 93, zapis z 6 III 1925.

${ }^{44}$ Ibidem, z. 96, zapis z 19 III 1926.

45 B. Tracz, op. cit., s. 44.

${ }^{46}$ W. Konopczyński, „Dziennik”, z. 100, zapis z 26 IV 1927. Szerzej zob. J. Maternicki, Władysław Konopczyński, jego miejsce i rola w życiu krakowskiego środowiska historycznego w latach 1918-1939, „Przegląd Humanistyczny” 29, 1985, 3-4, s. 123; B. Tracz, op. cit., s. 45

${ }^{47}$ Central'nij Deržavnij Istoričnij Archiv Ukraïni, L'viv (dalej: CDIAUL), f. 711, op. 1, spr. 114, List W. Konopczyńskiego do J. Ptaśnika, Kraków, 27 VI 1927.

${ }^{48}$ W. Konopczyński, „Dziennik”, z. 101, zapis z 5 X 1927. 
powołany przez Zarząd krakowskiego oddziału PTH 10 stycznia 1928 r. w składzie: Konopczyński, Feldman i Grodecki ${ }^{49}$. Inauguracyjne, bardzo liczne posiedzenie sekcji miało miejsce 1 lutego 1928 r. Rozpoczęło się ono doskonałym wystąpieniem Feldmana pt. „Omówienie drugiego tomu nowego wydania Dziejów Polski Michała Bobrzyńskiego", po czym głos zabrał Konopczyński, który mówił o swojej polemice z ostatnim stańczykiem $^{50}$. Podczas kolejnego posiedzenia (10 III 1928), referował ponownie Feldman na temat Bismarcka i Komisji Kolonizacyjnej. Po jego wystąpieniu Konopczyński zastanawiał się, „,o sobie myśli Sobieski o tym moim wychowanku - ale sądzę, że go już strawił"51. W tym względzie uczony był w błędzie, gdyż Sobieski zwalczał Feldmana aż do swojej śmierci. Zmarł przy pisaniu listu do Kolankowskiego, w którym prosił go, aby kandydował do objęcia po nim katedry, gdyż w przeciwnym razie obejmie ją Feldman ${ }^{52}$. W ślad za Sekcją Krytyczną powołano Komisję Historii Wojskowości, na czele której stanął Jan Dąbrowski. Konopczyński z przekąsem pisał w dzienniku: „nie sądzę, by więcej on zdziałał dla dziejów wojskowości niż ja"53.

Do pierwszego poważnego konfliktu Konopczyńskiego z władzami PTH doszło w maju 1928 r., kiedy to z inspiracji warszawskich członków, Handelsmana i Józefa Siemieńskiego, Zarząd Główny reprezentowany przez prezesa Stanisława Zakrzewskiego postanowił nadać honorowe członkostwo Józefowi Piłsudskiemu. Gdy o tych planach dowiedział się Konopczyński, stwierdził, że nie widzi w Krakowie „ani jednego historyka, który by się palił do udzielenia Piłsudskiemu godności honorowego członka Towarzystwa" ${ }^{54}$. Wyniesienie Marszałka zgłoszone na posiedzeniu Zarządu Głównego PTH (25 V 1928) spotkało się z gwałtowną opozycją Konopczyńskiego, którego poparli: Sobieski, Semkowicz i Kazimierz Tymieniecki ${ }^{55}$.

Profesor „wypowiedział mocne argumenty przeciw”, które potem dołączył jako votum separatum do protokołu Zarządu Głównego. W dziesięciu punktach Konopczyński poddał gruntowej krytyce decyzję władz

49 Ibidem, z. 102, zapis z 10 I 1928.

50 Ibidem, zapis z 1 II 1928.

51 Ibidem, zapis z 10 III 1928.

${ }^{52}$ Ibidem, z. 126, zapis z 6 IV 1935.

53 Ibidem, z. 103, zapis z 19 III 1928.

${ }^{54}$ Ibidem, zapis z 23 V 1928.

55 Ibidem, zapis z 25 V 1928. W sporze z Handelsmanem Konopczyńskiego miał wspierać także jego uczeń Feldman, jednak wrogi mu Sobieski nie dopuścił go do udziału w Walnym Zgromadzeniu PTH. Ibidem, zapis z 15 V 1928. Szerzej zob. T. Kondracki, Polskie Towarzystwo Historyczne, s. 83. 
Towarzystwa. W pierwszym punkcie podnosił, że „wbrew rozpowszechnionej opinii" wniosek o mianowanie Piłsudskiego członkiem honorowym PTH „podpisała nie większość członków warszawskiego oddziału, lecz tylko pewna grupa czynnych historyków oraz dziesiątki nieprodukcyjnych na polu naukowym miłośników; nie podpisało go wielu członków naprawdę dla nauki zasłużonych". W piątym punkcie utrzymywał, że

statut Towarzystwa przewiduje nadanie członkostwa honorowego osobie zasłużonej dla rozwoju Towarzystwa lub na polu nauk historycznych. O zasługach kandydata dla Towarzystwa nie wiadomo nic. Jego znane zasługi na polu nauk historycznych polegają na ułamkowych studiach nad powstaniem styczniowym, na wydaniu paru osobistych pamiętników i na ogłoszeniu książki o Roku 1920, którą autor pisał z pomocą podwładnych oficerów. Marszałek nie pierwszy zajął się odtworzeniem współczesnej historii wojskowej, a do rozbudzenia dalszych badań nad wojną polsko-bolszewicką przyczynił się głównie wywołaniem ostrych sporów z innymi generałami.

W kolejnym punkcie uczony dowodził, iż

nie ulega wątpliwości, że wnioskodawcy warszawscy pragnęli głównie uczcić polityczne zasługi marszałka Piłsudskiego, a jako pozór wysunęli zasługi dla nauki. Nie wdając się w ocenę jego polityki, ani nie tykając jego osobistego charakteru, którego różne cechy mogą budzić głęboką cześć, trzeba jednak zaznaczyć, że takie odznaczenie mężów stanu dyplomami naukowymi przystoi jedynie instytucjom o charakterze wszechstronnym, zwłaszcza uniwersytetom, a nie towarzystwom specjalnym. Wilson, Clémenceau, Balfour, Dmowski, Beneš nie stali się autorytetami w zakresie nauk reprezentowanych przez wydziały, które im ofiarowały doktoraty honorowe ${ }^{56}$.

Konopczyński zdawał sobie sprawę, że celem władz PTH było „zrobić marszałka Piłsudskiego autorytetem wśród historyków", co jego zdaniem „podcinało niezależność nauki, degradowało ją i obrażało”. Profesor z naciskiem podkreślał, że „nie należy się tytuł członka honorowego Polskiego Towarzystwa Historycznego człowiekowi, który wolnej i uczciwej pracy historycznej nie szanuje; nie wypada tego tytułu nadawać w murach wszechnicy, której godność doktorską tenże kandydat w brukowym piśmie ośmieszał". Na zakończenie historyk ze smutkiem pisał, że

${ }^{56}$ APAN, PTH I-3, j.a. 3, Votum separatum Władysława Konopczyńskiego do proo tokołu z posiedzenia Zarządu Głównego PTH, Lwów, 25 V 1928. Stąd poniższe cytaty. Skrótową wersję dokumentu jako pierwszy zacytował T. Kondracki, Polskie Towarzystwo Historyczne, s. 135. 
najcenniejszym naszym skarbem jest nie zasiłek ministerialny, ale współpraca dla wspólnej idei - i oparta na niej powaga instytucji. Co nastąpi, jeżeli za przykładem wnioskodawców warszawskich inni rozpoczną agitację za odznaczeniem generała Sikorskiego, R. Dmowskiego lub innych polityków i spróbują podpierać swe zabiegi terrorem, podstępem, pokusą, groźbą rozłamu? Co jeżeli na następne Walne Zgromadzenie któryś z oddziałów przywiezie nam dla dobra Towarzystwa kandydaturę komendanta Rydza-Śmigłego, albo płk. Sławka, albo płk. Wieniawy Długoszowskiego? Kłótnia zamiast zgody, służalstwo zamiast majestatu nauki, osława zamiast sławy to byłoby gorsze niż utrata materialnego zasiłku. Do sprawy, która może mieć takie następstwa, ręki nie przyłożę.

Pomimo gwałtownego sprzeciwu krakowskiego badacza, zebrani na Walnym Zgromadzeniu PTH (26 V 1928) delegaci zdecydowaną większością głosów uchwalili, aby nadać Marszałkowi honorowe członkostwo. W tajnym głosowaniu 28 członków opowiedziało się za, 4 było przeciw, a 2 wstrzymało się ${ }^{57}$. Konopczyński zapisał w dzienniku, że

nie było wyjaśnione, kto oddaje głosy za nieobecnych; niby dla usunięcia tej trudności Zakrzewski zaproponował, a Sobieski przyjął na dziś zasadę głosowania par têtes, a nie par mandats. Kiedy Zakrzewski wniósł projekt warszawski, 5-6 stupajków powstało z miejsc, reszta, tj. blisko 30 osób, siedziało. Również po przegłosowaniu oklaski były mizerne. Ja oddałem kartkę skazaną na unieważnienie: „widząc w sposobie głosowania naruszenie zasad ustrojowych naszego Towarzystwa, tudzież zerwanie z praktyką już obowiązującą nie mogę oddać głosu - Władysław Konopczyński”. Kiedy zaproponowano wybór zarządu przez aklamację, wyszedłem, bo i to jest bezprawne. Zaproszenia na czarną kawę do pp. Zakrzewskich jako „Targowiczan” nie przyjąłem ${ }^{58}$.

Konopczyński był tak oburzony postępowaniem Zakrzewskiego i Handelsmana, że gdy dwa tygodnie później Dąbrowski zaprosił go do domu na herbatę, odmówił ze względu na ich obecność 59 .

Między 28 listopada a 4 grudnia 1930 r. odbył się w Warszawie V Zjazd Historyków Polskich, poświęcony 100 . rocznicy wybuchu powstania listopadowego i 500. rocznicy śmierci wielkiego księcia Witolda. Tematyka zjazdu miała dotyczyć historii wojskowości, a dwa plenarne referaty zarezerwowano dla Wacława Tokarza i Szymona Askenazego. Kongres obradował w obecności prawie 700 uczestników, zabrakło jednak na

57 APAN, PTH I-3, j.a. 2, Protokół Walnego Zgromadzenia Delegatów PTH, Lwów, 26 V 1928. Zob. też T. Kondracki, Polskie Towarzystwo Historyczne, s. 136.

58 W. Konopczyński, „Dziennik”, z. 103, zapis z 26 V 1928.

59 Ibidem, zapis z 8 VI 1928. 
nim Konopczyńskiego, który demonstracyjnie odmówił udziału ${ }^{60}$. Przyczyną był konflikt polityczny związany z rozwiązaniem Sejmu i Senatu, prześladowaniem opozycji, której wybitnych przedstawicieli uwięziono w twierdzy brzeskiej, oraz zaproszeniem do wzięcia udziału w obradach prezydenta Ignacego Mościckiego i Piłsudskiego, pełniącego wówczas funkcję premiera. W swojej decyzji profesor nie był odosobniony, wcześniej z podobnych pobudek odmówili wzięcia udziału w zjeździe Wacław Tokarz, Stefan Czarnowski, Marian Kukiel, Stanisław Kot i Szymon Askenazy ${ }^{61}$. Sobieski ostrzegał Zakrzewskiego przed masową absencją krakowskich historyków, gdyż pod Wawelem mówiło się, iż „na zjazd pojadą tylko Sobieski i [Kazimierz] Piwarski"62. Radził on, aby Zakrzewski wpłynął na Handelsmana, by ten zrezygnował z odczytu na sesji plenarnej na rzecz Tokarza ${ }^{63}$. Wiedząc z autopsji, że w takich sytuacjach Zakrzewski się zacietrzewiał i pozostawał nieugięty, Sobieski prosił o interwencję Bujaka ${ }^{64}$. Jednak rady te zostały zlekceważone, a jak dowodził w liście do Michała Bobrzyńskiego Stanisław Estreicher, kongres

miał bardzo przykry przebieg. Zamierzony był jako zjazd dla uczczenia [18]31-ego roku. Rozbiło się to o rywalizację Handelsmana z Askenazym. Ten drugi miał pretensję (i słuszną), aby on zagrał pierwsze skrzypce, a Handelsman proponował duet. Askenazy powiedział mu: „Polska dużo zniesie, ale to, aby o [18]31-ym roku mówili dwa główne referaty Askenazy i Handelsman, to byłoby za dużo". Skończyło się na tym, że referat główny wygłosił Handelsman, polemizując cały czas z Askenazym, aczkolwiek podobno jego

${ }^{60}$ „O 4-ej posiedzenie delegacji zjazdowej, potem zarządu. Żale Zakrzewskiego na Askenazego. Moje non possumus - jedyny mój głos w dyskusji. Obraza Siemieńskiego na Zakrzewskiego. Ulotniłem się bez powitania z gen. Stachiewiczem, a o 11-ej pojechałem osobowym pociągiem do Krakowa”, ibidem, z. 112, zapis z 28 XI 1930; „Ze względu na panujące w Warszawie stosunki, tudzież z innych przyczyn udziału w zjeździe nie wezmę", APAN, PTH I-3, t. 84, List W. Konopczyńskiego do Komitetu V Zjazdu Historyków Polskich w Warszawie, Kraków, 9 XI 1930, k. 58; „Również Konopczyński mi oświadczył, że wycofuje swój udział w zjeździe i domaga się zwołania zarządu w Krakowie. Strachy na lachy! Zrobi mi awanturę pewnie na zarządzie o głosowanie", BO, 7349 III, t. 7, rkps, List W. Sobieskiego do S. Zakrzewskiego, Mszana Dolna, 2 X 1930; „Na zjeździe historyków nie byłem, podobnie jak Askenazy, Tokarz, Kot i Kukiel i wielu innych. Za wiele tam miało być brudasów i niewykluczone hocki-klocki”, BO, Przyb. 187/00, t. 5, rkps, List W. Konopczyńskiego do M. Loreta, Kraków [1930], k. 287.

${ }^{61}$ BJ, 8101, rkps, List S. Estreichera do M. Bobrzyńskiego, Lwów, 17 III 1935. Zob. też T. Kondracki, Polskie Towarzystwo Historyczne, s. 193-201.

${ }^{62}$ BO, 7349 II, t. 7, rkps, List W. Sobieskiego do S. Zakrzewskiego, Kraków, 9 VIII 1930.

${ }^{63}$ Ibidem, List W. Sobieskiego do S. Zakrzewskiego, Kraków, 23 XI 1930.

${ }^{64}$ Ibidem, Przyb. 120/69, List W. Sobieskiego do F. Bujaka, Kraków, 23 XI 1930. 
nazwiska nie wymieniał. Drugim szkopułem była kwestia protektoratu, nieprzyjętego zresztą dotąd na zjazdach naukowych. Grupa oficerów biorąca udział w zjeździe wraz z innymi zwolennikami rządu żądała, aby prosić o protektorat Piłsudskiego, co wywołało oburzenie przeciwników. Skończyło się na tym, że poproszono na protektorów Prezydenta Państwa i Prezydenta Rady Ministrów jako takich. Ale z tego powodu nie wziął udziału w zjeździe Tokarz i kilku innych ${ }^{65}$.

Konflikt na zjeździe warszawskim poprzedziły spory wokół powstania Polskiego słownika biograficznego i zmian w statucie $\mathrm{PTH}^{66} .3$ czerwca $1929 \mathrm{r}$. na posiedzeniu Zarządu Głównego PTH we Lwowie Konopczyński zgłosił wniosek o zmianę statutu ${ }^{67}$. Niestety protokoły ani dzienniki nie wyjaśniają, czego dotyczyły proponowane zmiany. Informacje na ten temat pojawiają się natomiast w korespondencji Konopczyńskiego z Teofilem Emilem Modelskim. Naszemu uczonemu chodziło o

usunięcie defektów następujących: 1. Nie ma racji bytu podział członków Towarzystwa na czynnych i zwyczajnych, a gdyby on miał istnieć, to „czynnych" członków powinny by kwalifikować zarządy miejscowe, a nie Zarząd Główny we Lwowie, który o ich czynnościach dokładnie nie wie. 2. Wadliwy jest skład Walnego Zgromadzenia. Przekształcając Towarzystwo w związek kół lokalnych, starano się za pomocą sztucznych środków utrzymać przewagę Lwowa, skutkiem czego członkowie Zarządu Głównego sami sobie uchwalają absolutorium. Nie chcemy usuwać z Walnego Zgromadzenia ani tych członków Zarządu Głównego, ani członków honorowych, niech oni mają głos doradczy i inicjatywę, ale decyzja powinna należeć do przedstawicieli oddziałów, wybranych proporcjonalnie do liczebności tychże. 3. Doświadczyliśmy tego, że przepisy o zastępcach członków Zarządu Głównego są niemal martwą literą: zastępcę z łatwością uzyskuje członek lwowianin, ale nie krakowianin, poznańczyk czy wilnianin. Na przyszłość powinny zastępców wyznaczać same miejscowe oddziały. 4. Chaotycznie i niezgodnie ze statutem odbywają się wybory do Zarządu Głównego. Próbujemy to uporządkować w tym duchu, aby Walne Zgromadzenie mogło wyraźną większością, a nie przez aklamację wyrażać zaufanie prezesowi, a potem, choćby i przez aklamację kompromisowo wybierać resztę zarządu ${ }^{68}$.

${ }^{65}$ BJ, 8101, rkps, List S. Estreichera do M. Bobrzyńskiego, Kraków, 16 XII 1930. Zob. też T. Kondracki, Polskie Towarzystwo Historyczne, s. 201.

${ }^{66}$ Zagadnienie to zostało omówione przez Piotra Bilińskiego, Władysława Konopczyńskiego „boje” o kształt Polskiego słownika biograficznego w latach 1928-1939, „Klio Polska. Studia i materiały z dziejów historiografii polskiej”, t. 7, 2015, red. A. Wierzbicki, s. 107-141.

67 Szerzej zob. T. Kondracki, Polskie Towarzystwo Historyczne, s. 83-89.

${ }^{68}$ Archiwum Uniwersytetu Jagiellońskiego, 126/14, rkps, List W. Konopczyńskiego do T.E. Modelskiego, Kraków, 14 II 1929. 
Postawiony przez Konopczyńskiego wniosek szedł tak daleko, że nawet zaprzyjaźniony z nim Bujak negatywnie go zaopiniował ${ }^{69}$. Z krytyką wystąpił także Handelsman, który postawił wniosek, aby upoważnić zarząd do powołania komisji statutowej dla rozpatrzenia propozycji krakowskiego kolegi. Poparli to Siemieński i Zakrzewski. Z kolei Tymieniecki zaakceptował początkowe punkty, jednak odrzucił „parlamentaryzację”. Nawet obecni na posiedzeniu krakowscy historycy Sobieski i Semkowicz nie poparli wniosku Konopczyńskiego. Jedyne wsparcie otrzymał od Modelskiego ${ }^{70}$. „Znalazłem się tedy w rażącej mniejszości” - konstatował uczony ${ }^{71}$. Po południu na Walnym Zgromadzeniu PTH po dłuższej dyskusji, w której brali udział Adam Vetulani, Kazimierz Tyszkowski i Zakrzewski, opowiedziano się większością głosów za wnioskiem Handelsmana o powołaniu komisji statutowej, która rozpatrzy wnioski Konopczyńskiego i przygotuje sprawozdanie na najbliższe posiedzenie $^{72}$. Profesor słusznie zauważył, że uchwała miała na celu odłożenie sprawy ad acta, ponieważ komisja statutowa nie istniała i nikt poważnie nie myślał o jej powołaniu ${ }^{73}$. Na drugi dzień odbyło się posiedzenie Zarządu Głównego PTH, na którym dyskutowano sprawę słownika biograficznego. Pomimo narastającej irytacji Konopczyński, ze względu na wagę zapadających tam uchwał, wziął w nim udział ${ }^{74}$. Widać z tego, że w istotnych sprawach umiał powściągnać emocje i wspólnie działać na rzecz rozwoju nauk historycznych. Należy jednak pamiętać, że jego projekt wyraźnie zmierzał do osłabienia pozycji lwowskiej centrali na rzecz środowisk lokalnych, przede wszystkim Krakowa (ze względu na liczbę członków).

69 „Przesłałem Tyszkowskiemu do Lwowa nasze wnioski w sprawie zmiany statutu PTH. Uważamy, że skoro już tę sprawę rusza się z miejsca, to trzeba usunąć i większe braki, i mniejsze, usunąć zwłaszcza nieład i niesprawiedliwość. Ty, o ile wiem, jesteś referentem takich spraw organizacyjnych, więc rozważ, proszę, nasze propozycje, a chyba uznasz je za słuszne", BO, Przyb. 120/58, rkps, List W. Konopczyńskiego do F. Bujaka, Kraków, 18 V 1929; „Wnioski Twoje o zmianie statutu PTH czytałem i referowałem na posiedzeniu Zarządu - jestem przeciwny usunięciu kategorii członków czynnych poza tym część twoich propozycji wydaje mi się pożądana, część obojętna. Na Walnym Zgromadzeniu będziesz sam referował", BJ, Przyb. 68/61, rkps, List F. Bujaka do W. Konopczyńskiego, Lwów, 22 V 1929.

70 APAN, PTH I-3, j.a. 3, Protokół z posiedzenia Zarządu Głównego PTH, Lwów, 3 VI 1929. Zob. też T. Kondracki, Polskie Towarzystwo Historyczne, s. 85.

${ }^{71}$ W. Konopczyński, „Dziennik”, z. 107, zapis z 3 VI 1929.

72 APAN, PTH I-3, j.a. 2, Protokół z Walnego Zgromadzenia PTH, Lwów, 3 VI 1929. Zob. też T. Kondracki, Polskie Towarzystwo Historyczne, s. 85.

73 W. Konopczyński, „Dziennik”, z. 107, zapis z 3 VI 1929.

74 APAN, PTH I-3, j.a. 3, Protokół z posiedzenia Zarządu Głównego PTH, Lwów, 4 VI 1929. Zob. też W. Konopczyński, „Dziennik”, z. 107, zapis z 4 VI 1929. 
Wyprzedzając nieco opowieść, dodać należy, że opieszałość w realizacji przyjętych ustaleń co do powołania komitetu statutowego i rozpatrzenia wniosków Konopczyńskiego spowodowała jego krytyczne wystąpienie podczas Walnego Zgromadzenia Delegatów (21 VI 1931). Konopczyński wygłosił „,z niebywałą swadą opozycyjną mowę streszczającą się w trzech zadaniach: statut, słownik, zjazd"75. Poddał krytyce mało energiczną działalność prezydium, domagał się - jak czytamy w protokole - „wykonania powziętej już przed dwoma laty uchwały Walnego Zgromadzenia powołania komisji statutowej, która by przeprowadziła zmiany w ustroju Towarzystwa”, ganił „stanowisko prezydium w sprawie niewzięcia udziału w pracach nad słownikiem biograficznym”, występował „przeciwko powierzaniu protektoratu honorowego nad V Zjazdem Historyków Polskich Józefowi Piłsudskiemu". Po nim głos zabrał Sobieski, odczytując „rezolucję Oddziału krakowskiego”, w której wyrażono „życzenie, aby na poziom naukowy «Kwartalnika Historycznego» zwracano na przyszłość baczniejszą uwagę, w szczególności na poziom rozpraw, recenzji i polemik; ponadto, aby się starano ze względu na panoszące się głosy krytyki o staranne przygotowanie dalszych zeszytów bibliografii Finkla". Następnie Dąbrowski uzasadnił uchwałę historyków krakowskich. Na zarzuty Konopczyńskiego i Sobieskiego odpowiedział, „unikając zwady”, Handelsman. Według niego, „brak organizacji zjazdu historycznego był wynikiem rozdwojenia organizacji między dwa oddziały"; w sprawie słownika biograficznego utrzymywał, że PTH powinno wziąć należny udział w jego redagowaniu i zapewnić sobie wpływ na redakcję ${ }^{76}$. Następnie głos w dyskusji zabrał Zakrzewski, który „tumanił, jak zawsze, co mu wkrótce wytknąłem" - zapisał diarysta. Jednak w polemice z nim uczony okazał się bardzo powściągliwy „ze względu na jutrzejszą naradę słownikową zwołaną przez Tyszkowskiego"77. Z tejże przyczyny nie zabierał głosu na kolejnym posiedzeniu Zarządu Głównego PTH (22 VI 1931)78. Jak słusznie zauważył współczesny badacz Tadeusz Kondracki, „sprawy dyskutowane w tak gorącej atmosferze w latach 1929-1931 dotyczyły, jeżeli nie wprost usunięcia TMH ze struktur PTH, to w każdym razie daleko idącego ograniczenia jego uprawnień". Jego zdaniem, Konopczyński, odwołując się „do poczucia egalitaryzmu - zasady równych praw i obowiązków

75 W. Konopczyński, „Dziennik, z. 113, zapis z 21 VI 1931.

76 APAN, PTH I-3, j.a. 2, Protokół z Walnego Zgromadzenia Delegatów PTH, Lwów, 21 VI 1931 r. Zob. też T. Kondracki, Polskie Towarzystwo Historyczne, s. 84.

77 W. Konopczyński, „Dziennik”, z. 113, zapis z 21 VI 1931.

78 APAN, PTH I-3, j.a. 3, Protokół z Walnego Zgromadzenia Delegatów PTH, Lwów, 22 VI 1931. 
wszystkich oddziałów PTH”, zjednywał sobie „głosy wielu członków Zarządu Głównego (poza warszawskimi)"79.

Niewątpliwie w swoich poczynaniach profesor był bardzo skuteczny, gdyż w nowelizacji statutu PTH zatwierdzonej we wrześniu 1929 r., postanowienia faworyzujące stolicę zostały pominięte. Jak można wnioskować z dostępnych źródeł, we wszystkich wymienionych wyżej sprawach krzyżowały się sprzeczne interesy Warszawy, Lwowa i Krakowa lub patrząc z innej perspektywy - sanacyjne i endeckie. Spór pomiędzy Krakowem a Warszawą i Lwowem wszedł wtedy w szczególnie ostrą fazę, na co znaczny wpływ miało nadanie członkostwa honorowego PTH Piłsudskiemu. Od tego momentu Konopczyński coraz częściej stosował metodę obstrukcji podczas posiedzeń Zarządu Głównego PTH i ograniczał się do prac w Sekcji Krytycznej krakowskiego oddziału oraz w redakcji PSB. Jeszcze bardziej radykalnie nastawiony w stosunku do prezydium Towarzystwa był Kot, który „wojowniczo się odgrażał na Zakrzewskiego, że trzeba wcześniej wymusić Walne Zgromadzenie i przygnieść prezesa taką krytyką, że albo by zrezygnował, albo my «Kwartalnik» weźmiemy do Krakowa"80.

Z napięciem narastającym w Zarządzie Głównym PTH zbiegła się sprawa konfliktu w krakowskim oddziale pomiędzy Kutrzebą i Sobieskim. Spór dotyczył wydawnictw naukowych PTH, które - wbrew wcześniejszym ustaleniom - Sobieski jako prezes oddziału wydrukował w Drukarni św. Wojciecha w Poznaniu, a nie w kierowanej przez Kutrzebę drukarni UJ. Wzburzony Kutrzeba nie dość, że zarzucił nieobecnemu na posiedzeniu Sobieskiemu nielojalność względem zarządu, to jeszcze z dezynwolturą stwierdził, że druk w drukarni UJ byłby o wiele tańszy ${ }^{81}$. W dzienniku Konopczyński stwierdził, że Sobieski „będzie miał twardy orzech do zgryzienia z Kutrzebą, który na jego umowy z drukarniami się sierdzi"82. Rzeczywiście natężenie konfliktu nastąpiło na następnym posiedzeniu, kiedy Sobieski wyjaśnił, że przeniesienie wydawnictw do Poznania „spowodowane było chęcią przyspieszenia druku, ponieważ drukarnia uniwersytecka była zajęta pracami Akademii Umiejętności. Tymczasem pieniądze trzeba było możliwie szybko wydać ze względu na sprawozdanie roczne, które zarząd musiał wysłać p. [Stanisławowi]

79 T. Kondracki, Polskie Towarzystwo Historyczne, s. 84-86.

80 W. Konopczyński, „Dziennik”, z. 116, zapis z 21 III 1931.

${ }^{81}$ Archiwum Nauki Polskiej Akademii Nauk i Polskiej Akademii Umiejętności w Krakowie (dalej: AN PAN i PAU Kr), PTH-35, Protokół z posiedzenia zarządu krakowskiego Oddziału PTH, Kraków, 31 X 1929.

${ }^{82}$ W. Konopczyński, „Dziennik”, z. 109, zapis z 3 I 1930. 
Michalskiemu. Gdybyśmy drukowali w drukarni UJ, mielibyśmy zaledwie cztery prace, tymczasem obecnie mamy już siedem prac". Odpierając zarzut wyższych kosztów, Sobieski stwierdził, że „ceny krakowskie nie są niższe od cen Drukarni św. Wojciecha, gdyż arkusz w drukarni UJ liczy 260 zł, a w Drukarni św. Wojciecha 240 zł. Poza tym Drukarnia św. Wojciecha przyznała bonifikatę w wysokości 300 zł”. Sobieski zażądał od zarządu wyjaśnień w sprawie sformułowania Kutrzeby o jego nielojalności i wykreślenia tych słów z protokołu. Starając się udzielić wzburzonemu prezesowi odpowiedzi, Dąbrowski stwierdził, że zarząd nie może udzielić mu żądanych wyjaśnień ani też wykreślić słów z protokołu ze względu na nieobecność Kutrzeby. Za wnioskiem Dąbrowskiego opowiedzieli się Grodecki i Konopczyński, którzy stwierdzili, że dopiero po pojawieniu się Kutrzeby i jego zgodzie na wycofanie inkryminowanych słów będzie można podjąć odpowiednią uchwałę o wykreśleniu ich z protokołu ${ }^{83}$.

Jednak Kutrzeba nie miał zamiaru przepraszać Sobieskiego, a przy tym zrzekł się członkostwa w Towarzystwie i godności wiceprezesa. W tej sytuacji Sobieski zwrócił się do niego z prośbą o zgodę na wykreślenie z protokołu słów o nielojalności i cofnięcie rezygnacji z prac w krakowskim oddziale PTH. Tłumaczył swojemu antagoniście, że polecił

odbijać część prac Towarzystwa Historycznego w Drukarni św. Wojciecha sądząc, że uchwała zarządu (aby drukować w drukarni uniwersyteckiej) nie wyłączała bezwzględnie innych drukarni. [--] Spieszyłem się zaś z drukiem, gdyż w pamięci mi utkwiły słowa Pańskie na posiedzeniu zarządu (17 stycznia 1929), że „pieniądze od p. Michalskiego należy jak najrychlej wydawać". Tymczasem druk nie mógł raźno postępować z powodu nawału prac w drukarni uniwersyteckiej [--], więc część prac postanowiłem pospiesznie drukować u św. Wojciecha ${ }^{84}$.

Kutrzeba odpowiedział krótko, stwierdzając, że „przyjmuje do wiadomości [- ] usprawiedliwienie”, godzi się „cofnać rezygnację ze stanowiska członka i zastępcy przewodniczącego zarządu Koła”, a także „na wykreślenie słów o nielojalności”"85.

Chociaż omówiony spór udało się załagodzić, szybko doszło do nowego konfliktu. Na posiedzeniu krakowskiego oddziału (7 III 1931) Grodecki wygłosił referat pt. „Iwo Odrowąż biskup krakowski”, po którym

83 AN PAN i PAU Kr, PTH-35, Protokół z posiedzenia zarządu krakowskiego Oddziaa łu PTH, Kraków, 8 II 1930. Zob. też W. Konopczyński, „Dziennik”, z. 109, zapis z 8 II 1930.

${ }^{84}$ AN PAN i PAU Kr, K III-11, j.a. II/93, List W Sobieskiego do S. Kutrzeby, Kraków, 5 III 1930.

${ }^{85}$ Ibidem, j.a. II/98, List S. Kutrzeby do W. Sobieskiego, Kraków, 11 III 1930. 
Kutrzeba „napastliwie zrobił coś pięć niezbyt poważnych zarzutów. Grodecki odpowiadał bardzo powściągliwie, a wtedy Kutrzeba napadł nań jeszcze gwałtowniej, jak na żaka, w obecności coś dziesięciu jego słuchaczy. Sobieski nie wiedział, co począć. Kutrzeba przed wyjściem zapowiedział, że jego noga więcej u nas nie postanie w KKTH, bo Grodecki w drugiej replice uderzył pięścią w stół. Skandal niebywały" - konstatował Konopczyński ${ }^{86}$. W konsekwencji Grodecki przez kilka lat opuszczał posiedzenia Towarzystwa, Kutrzeba zaś nie pojawiał się na nich przez kilka miesięcy. W liście do prezesa żądał wyciągnięcia konsekwencji w stosunku do młodszego kolegi za niedopuszczalne bicie pięścią w stół, podniesiony głos i „nieparlamentarne słownictwo" ${ }^{87}$. Jednak Sobieski nie dopatrzył się w zachowaniu Grodeckiego uchybienia godności profesora i nie słyszał „nieparlamentarnego słownictwa"88. Obecny na posiedzeniu zarządu Konopczyński stwierdził, że „niepotrzebnie wdano się w godzenie Kutrzeby z Grodeckim. Ja widzę jedyną drogę postępowania przez sąd polubowny” ${ }^{9}$. Gdy „próby pogodzenia Kutrzeby z Grodeckim podejmowane przez Semkowicza i Dąbrowskiego zawiodły"90, na kolejnym posiedzeniu zarządu krakowskiego Oddziału PTH uchwalono, , aby na Walnym Zebraniu nie podnosić sprawy między prof. Grodeckim a prof. Kutrzebą

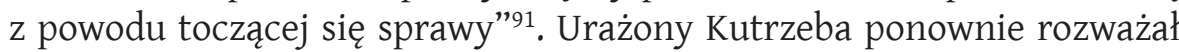
możliwość zrzeczenia się wiceprezesury oddziału i wystąpienie z $\mathrm{PTH}^{92}$.

Konopczyński ze smutkiem stwierdzał, że „sprawy Towarzystwa Historycznego i u nas, i we Lwowie przechodzą kryzys. Sobieski chory i podcięty. Kutrzeba i Grodecki wystąpili, a tam we Lwowie nagła pustka w kasie. [--] W Krakowie ubyli z jego posiedzeń Kutrzeba, Grodecki, Fijałek, Papée, [Adam] Wolański, [Władysław] Tomkowicz. Nie ma takiego Chief Whipa, co by ściągnął na posiedzenia rozpierzchłe żywioły"93. Jednak po paromiesięcznym zastoju, gdy Sobieski wyjechał na badania naukowe do Paryża, sprawy Towarzystwa uległy radykalnej zmianie ${ }^{94}$.

86 W. Konopczyński, „Dziennik”, z. 113, zapis z 7 III 1931.

${ }^{87}$ BJ, 9555 II, rkps, List S. Kutrzeby do W. Sobieskiego, Kraków, 17 III 1931, k. 154.

88 AN PAN i PAU Kr, PTH-35, Protokół z posiedzenia zarządu krakowskiego Oddziaa łu PTH, Kraków, 24 IV 1931.

${ }^{89}$ W. Konopczyński, „Dziennik”, z. 113, zapis z 24 IV 1931.

${ }^{90}$ Ibidem, zapis z 8 V 1931.

${ }^{1}$ AN PAN i PAU Kr, PTH-35, Protokół z posiedzenia zarządu krakowskiego Oddziaa łu PTH, Kraków, 8 V 1931.

92 „Kutrzeba podobno wystąpił z Towarzystwa Historycznego. Ten człowiek niee dojdzie do samokrytycyzmu”, W. Konopczyński, „Dziennik”, z. 113, zapis z 21 III 1931.

${ }^{93}$ Ibidem, z. 115, zapisy z 8 X, 26 XI 1931.

94 Ibidem, z. 116, zapis z 13 II 1932. 
Korzystając bowiem z jego nieobecności, Kutrzeba z Feldmanem rozpoczęli energiczne starania o usunięcie go z prezesury. W sprawę zaangażowany był Konopczyński, który na posiedzeniu zarządu krakowskiego Oddziału PTH złożył wniosek, „aby zwołać nadzwyczajne zebranie ogólne. Będzie to trochę sejm inkwizycyjny, ale jeszcze nie egzekucyjny" - konstatował ${ }^{95}$. Kilka dni później odbyło się nadzwyczajne posiedzenie zarządu. Ze starych członków wzięli w nim udział Józef Muczkowski, ks. Fijałek, Leonard Lepszy, Adam i Abdon Kłodzińscy. Konopczyński referował „sprawy zjazdowe i Towarzystwa”. Dyskusja była dość żywa, przemawiali Kot, Dąbrowski, Kukiel, [Karol] Piotrowicz, [Sylwiusz] Mikucki i [Karol] Buczek. Brakowało tylko chorego na grypę Feldmana ${ }^{96}$. Spotkanie nie przyniosło wymiernych rezultatów, ale w gronie zarządu zaczęła kiełkować myśl o zmianie kierownictwa. Jak odnotował w dzienniku Konopczyński, „Feldman na wszystko widzi radę w odesłaniu Sobieskiego na honorowe członkostwo Towarzystwa Historycznego i w powołaniu Kutrzeby na prezesa. Moim zdaniem to żadne rozwiązanie. Kutrzeba swojej duszy nam nie da, a cudze pozraża. Podobno zresztą już żałuje swej napaści na Grodeckiego i gotów go zaspokoić" ${ }^{97}$. Zachowanie Feldmana martwiło Konopczyńskiego, który uważał, że uczeń zanadto

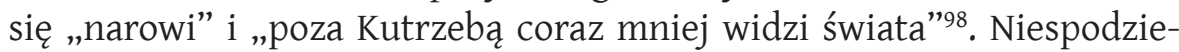
wanie dla wszystkich Sobieski skrócił swój pobyt w Paryżu i przyjechał do Krakowa, zaalarmowany przez Bujaka „o naszych pomrukach malkontenckich" 99 . Zaraz po powrocie zwołał posiedzenie zarządu krakowskiego Oddziału, podczas którego złożył rezygnację z funkcji prezesa ${ }^{100}$. Jako przyczyny swojej dymisji Sobieski wskazywał intrygi Konopczyńskiego, „który urażony na cały świat za to, że nie został zwyczajnym członkiem Akademii, chciał zostać prezesem w moje miejsce. Podnietę do rokoszu uzyskał od Kutrzeby, a zdaje się, że maczał w tym rękę i Handelsman"101. Na jego miejsce desygnowano Konopczyńskiego, po czym postanowiono o wszystkim poinformować Kutrzebę i zapytać, czy w związku z ustąpieniem Sobieskiego nie chciałby ponownie uczestniczyć w pracach oddziału $^{102}$. Kutrzeba zgodził się i niespodziewanie dla wszystkich wyraził

${ }^{95}$ Ibidem, zapis z 25 II 1932.

96 Ibidem, zapis z 5 III 1932.

97 Ibidem, zapis z 6 III 1932.

98 Ibidem, zapis z 22 III 1932.

99 Ibidem, zapis z 20 IV 1932.

100 AN PAN i PAU Kr, PTH-35, Protokół z posiedzenia zarządu krakowskiego Oddziaa łu PTH, Kraków, 22 IV 1932.

101 BO, Przyb. 120/69, rkps, List W. Sobieskiego do F. Bujaka, Kraków, 5 V 1932.

102 W. Konopczyński, „Dziennik”, z. 116, zapis z 22 IV 1932. 
życzenie objęcia prezesury, którą mu ofiarowali Kot, Dąbrowski i Feldman, nie zważając na wcześniejszy wybór Konopczyńskiego. Jakież było zaskoczenie tego ostatniego, gdy Kot oznajmił mu, że Kutrzeba został wybrany prezesem, a jemu pozostawiono wiceprezesurę. W tej sytuacji nie chciał jej przyjąć, lecz na skutek perswazji Dąbrowskiego, Kukiela i Feldmana ustąpił, choć obawiał się „dużej różnicy zdań z Kutrzebą”103. Z nominacji Kutrzeby był zadowolony ustępujący Sobieski, który uważał, że w ten sposób „wykiwał” Konopczyńskiego. Sądził, że niewątpliwy wpływ na wybór Kutrzeby miała jego pozycja naukowa w Krakowie i piastowanie funkcji sekretarza generalnego PAU. „Okazało się, że «gospodarcze» czynniki mają znaczny wpływ w dziejach ludzkości, albowiem wielu członków zarządu w Krakowie bierze pensje od Kutrzeby, jak Karol Piotrowicz jako dyrektor Biblioteki Akademii, jak Dąbrowski jako «sekretarz» działu tek rzymskich i zastępca Semkowicza, jak Konopczyński jako wydawca słownika biograficznego, i Feldman, który drukuje prace w Akademii itp."104.

Przy obejmowaniu stanowiska wiceprezesa Konopczyński postawił jednak warunek zażegnania konfliktu Kutrzeby z Grodeckim. Załatwienie sprawy powierzono Kotowi i Dąbrowskiemu, „których nie wiem, za co mam więcej podziwiać: za zręczność czy za niezręczność"105. Sporu długo nie udawało się załagodzić, gdyż „Grodecki wciąż boczył się na zarząd krakowskiego Oddziału PTH, najmniej na mnie. Więc do niego o tym piszę" - konstatował uczony ${ }^{106}$. W rolę mediatora zaangażował się z pomyślnym skutkiem Feldman i za jego namową Grodecki zgodził się brać udział w posiedzeniach ${ }^{107}$. Profesor zastanawiał się tylko, „kto będzie jednał różnych ludzi z Feldmanem, jeżeli on nie powściągnie swej drażliwości"108. Konopczyński nie mylił się w ocenie dawnego ucznia, gdyż obok głównego konfliktu w krakowskim Oddziale PTH toczył się mniejszy, „całkiem zresztą niezrozumiały”, pomiędzy Feldmanem i Lepszym $^{109}$. Na szczęście szybko doszło do pojednania. Konopczyński skwitował rzecz krótko: „Takim to idzie łatwo, nie jak mnie, który z [Stanisławem] Estreicherem od lat blisko dziesięciu, a z [Władysławem] Heinrichem od 3-4, ze Stanisławem Zakrzewskim od roku zerwałem na amen"110. Feldman potrafił obrazić się nawet na własnego mistrza, gdy

103 Ibidem, zapis z 23 IV 1932.

104 BO, Przyb. 120/69, rkps, List W. Sobieskiego do F. Bujaka, Kraków, 5 V 1932.

105 W. Konopczyński, „Dziennik”, z. 116, zapis z 24 IV 1932.

${ }^{106}$ Ibidem, z. 118, zapis z 8 X 1932.

107 Ibidem, z. 125, zapis z 13 XII 1934.

${ }^{108}$ Ibidem, z. 125, zapis z 15 XI 1934.

109 Ibidem, z. 121, zapis z 25 XI 1933.

110 Ibidem, z. 122, zapis z 17 I 1934. 
ten podczas obrad Sekcji Krytycznej poddał surowej ocenie książkę pt. Kraków i ziemia krakowska (Lwów 1934), którą autor Polski w dobie wielkiej wojny północnej współtworzył. Uczeń był „strasznie urażony o finał: że przemilczenie obozu narodowego tłumaczę «państwowym» charakterem wydawnictwa. Nawet nie chciał ze mną iść do domu" - konstatował Konopczyński ${ }^{111}$. Po raz drugi Feldman obraził się na byłego promotora, gdy ten skrytykował jego pracę Vergennes wobec Polski 1774-1787 (Cracovie 1931). Młody historyk „długo replikował”, po czym wyraził zdziwienie czytamy - „czemu swoich obiekcji nie przedstawiłem w Akademii przed drukiem". Ze względu na obecność zagranicznych gości Konopczyński nie kontynuował nieprzyjemnej dyskusji112. Rozsierdzony Feldman próbował się zrewanżować po wygłoszonym przez mistrza referacie o rokoszu Zebrzydowskiego. Konopczyński wspominał, że choć wykład „wypadł podobno bardzo dobrze i zrobił obiecujące wrażenie, sensację wywołał Feldman, atakując mnie za pogląd na Skargę i na doniosłość sprawy uzdrowienia sejmów. Odpowiedziałem mu suaviter in modo (aż się Kutrzeba dziwował), ale fortiter in re, że to były rzeczy bardzo na czasie, zrozumiałe i konieczne. Feldman ma nieszczęśliwą passę, przed tygodniem tak samo przegrał spór o Wielkopolskę z Kutrzebą"113. Konflikt wyciszył się po objęciu przez Feldmana katedry historii nowożytnej na UJ i publikacji przezeń dzieła Bismarck a Polska. Mając zagwarantowane środki utrzymania i wysoki status naukowy, autor Bismarcka szybko wrócił do równowagi psychicznej, wyzbył się drażliwości i ponownie zbliżył się do Konopczyńskiego, nazywając go „drogim mistrzem” ${ }^{114}$.

Obok konfliktu w krakowskim oddziale PTH narastało napięcie wokół prezesa Zakrzewskiego. Co prawda Konopczyński wraz Kutrzebą publicznie deklarowali, że „nie chcą ostrej walki ze Lwowem”, pragnęli jednak zmiany kierownictwa w centrali Towarzystwa ${ }^{115}$. Spory dotyczyły edycji PSB i wymuszonej rezygnacji PTH z tego przedsięwzięcia na rzecz PAU, pojawiających się trudności przy reedycji Bibliografii historii Polski Finkla, którą nieudolnie zajmował się protegowany Zakrzewskiego, Karol Maleczyński. Kryzys zaostrzył się podczas przygotowań i przebiegu warszawskiego Zjazdu Historyków Polskich w 1930 r. Sytuację dodatkowo skomplikowała nagła śmierć redaktora „Kwartalnika Historycznego”, Jana Ptaśnika, i zlecenie redakcji Zakrzewskiemu, który nie mógł sprostać powierzonemu zadaniu.

111 Ibidem, z. 125, zapis z 12 I 1935.

112 Ibidem, z. 129, zapis z 31 III 1936.

113 Ibidem, z. 129, zapis z 9 V 1936.

114 Ibidem, z. 132, zapis z 7 I 1938.

115 Ibidem, z. 116, zapis z 29 IV 1932. 
Na skutek krytyki krakowian na początku maja 1932 r. Zakrzewski zdecydował się złożyć rezygnację z prezesury na rzecz Bujaka, motywując to wzrostem dysonansów i chęcią uchronienia Towarzystwa przed dalszym rozdwojeniem ${ }^{116}$. W celu przeprowadzenia wyborów nowego prezesa Zakrzewski zwołał posiedzenie Zarządu Głównego i Walnego Zgromadzenia Delegatów PTH na 28 maja 1932 r. Przed wyjazdem do Lwowa członkowie krakowskiego Oddziału postanowili nie występować przeciwko ustępującemu prezesowi. Konopczyński zadeklarował, że będzie „klein und mild"117. Pomimo to na posiedzeniu Zarządu Głównego PTH skrytykował „przyklapniętego” Zakrzewskiego, szczególnie za opóźnienia w wydawaniu „Kwartalnika Historycznego”118. Domagał się, aby do współpracy z periodykiem zapraszano także historyków spoza Lwowa, co jakoby nie było realizowane ${ }^{119}$. Wreszcie profesor skrytykował nieudolny sposób reedycji Bibliografii Finkla i domagał się wstrzymania jej druku.

Przed posiedzeniem Walnego Zgromadzenia Delegatów krakowianie w kawiarni u George'a ustalili „podział ról”120. Na posiedzeniu, 29 maja 1932 r., wszystko przebiegało zgodnie z planem. Najpierw Kazimierz Lepszy poprosił „o wytłumaczenie zwłoki w wydaniu «Kwartalnika» w roku ubiegłym; co do przyszłości prosił o podawanie w piśmie sprawozdań ogólnych, a nie z dzieł łatwo dostępnych. Co do rozpraw domagał się dostosowania poszczególnych numerów «Kwartalnika» do bieżących rocznic”. Następnie Kazimierz Piwarski, omawiając zawartość „Wiadomości Historycznych”, domagał się „większego przeglądu czasopism” oraz postawił wniosek, „ażeby «Wiadomości» wychodziły bardziej regularnie, a zapiski były jak najszybsze". Z kolei Stanisław Kot wystąpił „przeciwko błędom w Bibliografii i poddał krytyce całe wydawnictwo”. Odpowiadając na postawione zarzuty „w sprawie Bibliografii - Zakrzewski - podał do wiadomości na podstawie uchwały ustępującego zarządu, że przyszły Zarząd Główny powoła Komisję, która pod przewodnictwem prof. Stanisława Kętrzyńskiego, a z udziałem przedstawicieli oddziałów krakowskiego, lwowskiego i poznańskiego, zajmie się tą sprawą"121.

Po dłuższej dyskusji Zakrzewski ustąpił z zajmowanego stanowiska, a delegaci wybrali na nowego prezesa rekomendowanego przez zarząd

116 Ibidem, z. 117, zapis z 9 V 1932.

117 Ibidem, zapis z 25 V 1932.

118 Ibidem, zapis z 28 V 1932.

119 APAN, PTH I-3, j.a. 3, Protokół z posiedzenia Zarządu Głównego PTH, Lwów, $28 \mathrm{~V} 1932$.

120 W. Konopczyński, „Dziennik”, z. 117, zapis z 29 V 1932.

121 APAN, PTH I-3, j.a. 2, Protokół z posiedzenia Walnego Zgromadzenia Delegatów PTH, Lwów, 29 V 1932. Zob. też T. Kondracki, Polskie Towarzystwo Historyczne, s. 139-140. 
Bujaka. Do zarządu powołano też dwóch nowych członków związanych z obozem rządzącym - Stefana Ehrenkreutza i Ottona Laskowskiego. Nowo wybrany Zarząd Główny zebrał się na pierwsze posiedzenie, na którym jednogłośnie wskazano nowego redaktora „Kwartalnika Historycznego" - Modelskiego. Skarbnikiem został ponownie Tadeusz Urbański, a sekretarzem Stefan Inglot ${ }^{122}$. Zmiana na stanowisku prezesa PTH nie uspokoiła nastrojów.

Trzy miesiące po wyborach Zakrzewski podał powody ustąpienia z funkcji prezesa PTH. W liście do Bronisława Dembińskiego pisał:

Zdecydowałem się jednak z nią rozstać właśnie dlatego, by się już ostatecznie nie zestarzeć jako prezes. Przyznam się także otwarcie, że cała ta praca znudziła mi się potężnie, a do tej nudy przyczyniły się nudne i nieciekawe małostki ludzkie, wiecznie w kółko te same. Nie bardzo mi się zresztą udało uciec, jak chciałem, gdyż musiałem zostać w zarządzie i wziąć na siebie lwowski Oddział Towarzystwa, srodze zaniedbany. Jednak na ogół ulżyło mi ogromnie i gotów jestem każdemu to samo radzić. I ja jeszcze chcę zrobić coś i skończyć rzeczy, od których robota prezesowska jednak mnie stale odrywała. Powiem, że senatorstwo o wiele mniej absorbuje. Jako prezes dałem, co mogłem, było to zresztą niewiele, starałem się przy tym porządnie, a następca [Bujak] daje mi gwarancję, że ma ambicję i będzie chciał coś zrobić. Nie mogę się skarżyć na współpracę kolegów; przeważnie mi pomagali bardzo, jeden tylko Kraków, co było zresztą i za Finkla, ze specjalną złośliwością, a z mniejszym już powodzeniem przeciwstawiał się inicjatywom naszym. Dziwne to zjawisko, a moim zdaniem upadek intelektualnego i naukowego Krakowa przynajmniej w obrębie naszego świata historycznego. A znowu rola eunucha prezydialnego, jak sam Pan Rektor przyzna, do mnie nie licuje. Nie będzie zresztą nim także i Franek [Bujak] ${ }^{123}$.

Od początku prezesury Bujak musiał się borykać z trudnościami finansowymi i nieprzychylnością sfer rządowych. Głównymi jego przeciwnikami byli związani z sanacją Laskowski, Ehrenkreutz, Kętrzyński i Handelsman, którzy wszyscy pragnęli nie tylko usunąć go z zajmowanego stanowiska, ale także przenieść centralę PTH do stolicy. W obronie nowo wybranego prezesa stanęło środowisko krakowskie z Konopczyńskim i Kutrzebą na czele ${ }^{124}$.

122 APAN, PTH I-3, j.a. 3, Protokół z posiedzenia Zarządu Głównego PTH, Lwów, 29 V 1932. Zob. też T. Kondracki, Polskie Towarzystwo Historyczne, s. 139-140.

${ }^{123}$ APAN, Oddział w Poznaniu, P III-34, j.a. 150, List S. Zakrzewskiego do B. Demm bińskiego, Lwów, 16 VIII 1932.

124 W. Konopczyński, „Dziennik”, z. 122, zapis z 19 XII 1933; BO, Przyb. 50/69, rkps, List S. Kutrzeby do F. Bujaka, Kraków, 19 V 1934, k. 451. 
Konflikt nasilał się, a spory pomiędzy Zarządem Głównym PTH a warszawskim Towarzystwem Miłośników Historii nie ustawały ${ }^{125}$. Bujak przeciwstawiał się planom zamieszczenia w statucie zapisu o możliwości tworzenia oddziałów terenowych TMH, ponieważ tworzyłoby to niepotrzebną konkurencję dla oddziałów PTH. Sporną kwestią była też sprawa wzajemnych rozliczeń finansowych. Nie mogąc porozumieć się z prezesem TMH Kętrzyńskim, Bujak planował zerwać stosunki między oboma Towarzystwami i założyć w stolicy oddział PTH, konkurencyjny dla TMH. Usilnie namawiał go do tego Konopczyński, który uważał, że byłby to mocny argument, mogący wpłynąć na porzucenie przez warszawian zamiarów wyemancypowania się spod władzy lwowskiej centrali ${ }^{126}$. Zamknięcie sporu przyniosło dopiero podpisanie nowej umowy pomiędzy Towarzystwami na posiedzeniu Zarządu Głównego PTH 29 maja $1934 \mathrm{r}^{127}$

Spotkanie miało burzliwy przebieg. „Warszawska trójca: Handelsman - Kętrzyński - Laskowski atakowali Bujaka"128. Prezes bronił się dzielnie, ale sprawa była przegrana, gdyż pomimo zawarcia porozumienia, trwający dwa lata konflikt z Warszawą osłabił jego pozycję w Zarządzie Głównym PTH. Podczas Walnego Zgromadzenia Delegatów 30 maja 1934 r. świadomy podziałów w środowisku Bujak zażądał, aby podczas mających się odbyć wyborów poparła go większość delegatów, w przeciwnym razie nie podejmie się pełnienia dalej funkcji prezesa. Wobec wyniku głosowania 29 głosów do 28 podał się do dymisji i opuścił salę. W drugim głosowaniu 30 historyków wybrało na stanowisko prezesa Zakrzewskiego ${ }^{129}$. Ustąpienie Bujaka nie wypłynęło jednak na uspokojenie nastrojów, gdyż

125 APAN, PTH-3, j.a. 3, Protokół z posiedzenia Zarządu Głównego PTH, Lwów, 29 I 1933.

126 W. Konopczyński, „Dziennik”, z. 119, zapis z 29 I 1933. Zob. też BO, Przyb. 120/58, rkps, List W. Konopczyńskiego do F. Bujaka, Kraków, 5 V 1934.

127 APAN, PTH I-3, j.a. 3, Protokół z posiedzenia Zarządu Głównego PTH, Lwów, $29 \mathrm{~V} 1934$.

128 W. Konopczyński, „Dziennik”, z. 123, zapis z 29 V 1934.

129 APAN, PTH I-3, j.a. 2, Protokół z posiedzenia Walnego Zgromadzenia Delegaa tów PTH, Lwów, 30 V 1934. Zob. też W. Konopczyński, „Dziennik”, z. 123, zapis z 30 V 1934: „Na Walnym Zgromadzeniu dyskusja trochę ciągniona za uszy, bo Bujaka trudno zganić, więc i do obrony nie było sposobności. Jan Dąbrowski zaskandalił przed wyborem komisji matki i odjechał, aby nie głosować wbrew Handelsmanowi. Sam Semkowicz miał mu powiedzieć, że go ma dość. Bujak wobec wyniku 29:28 podziękował. Zakrzewski dostał potem głosów 30 i przyjął. [Eugeniusz] Barwiński chciał nagrodzić Bujaka członkostwem honorowym, ale myśmy zaoponowali Semkowicz, Tymieniecki, ja, [Józef] Umiński. Ergo wileński zjazd oddany w nieczyste ręce (Zakrzewski ubabrał się w sprawie pożyczki z kasy zrzeszenia profesorów i docentów)”. T. Kondracki, Polskie Towarzystwo Historyczne, s. 141-142. 
jego stronnicy kontestowali działania nowego prezesa i popierających go sanacyjnych kręgów. Konopczyński był oburzony dokonanym wyborem, w dzienniku wspominał, że „w tym całym Lwowie naukowym to już prawie nikogo sympatycznego nie zostało. [Helena] Polaczkówna, Bujak, który zresztą znów zwłóczy". Irytował go też pomysł poświęcenia osobnego zeszytu „Kwartalnika” pamięci marszałka Piłsudskiego. Uważał, że taka publikacja wywołałaby w Towarzystwie jeszcze większy konflikt niż nadanie przed laty Piłsudskiemu honorowego członkostwa PTH. Obawiał się, że narastające napięcie zmusi go do wystąpienia z Towarzystwa, a może nawet do ustąpienia z katedry ${ }^{130}$. Pod wpływem tych niesprzyjających okoliczności zaczął rozważać możliwość rezygnacji z wiceprezesury krakowskiego oddziału PTH, wstrzymywał się z tą decyzją do rozstrzygnięcia się „spraw lwowskich i sprawy mojego dziekaństwa”131. Najwierniejszy uczeń Konopczyńskiego, Feldman, widząc jego nadwątlone nerwy „koniecznie chciał urządzić mistrzowi mały jubileusz trzydziestolecia pracy naukowej”. W tym celu zaagitował inne ośrodki naukowe w Polsce i „obmyślił taki plan, że uczniowie postarają się wydać książkę o pierwszym rozbiorze, którą ja mam napisać" - wspominał uczony ${ }^{132}$.

Po niespodziewanej śmierci Zakrzewskiego, 15 marca 1936 r., przed PTH stanął problem wyboru nowego prezesa. Naturalnym kandydatem na to stanowisko był Bujak ${ }^{133}$, ale niechętny mu Handelsman wysunął kandydaturę nestora z Poznania, Bronisława Dembińskiego ${ }^{134}$. W liście napisanym do Dembińskiego Konopczyński demaskował intrygę:

po śmierci St. Zakrzewskiego pojawiła się w Warszawie dążność do przeniesienia tam centrum PTH. Zdaje się, że teraz zrozumiano już szkodliwość tego pomysłu, ale jak sądzę, są tam inne projekty, których my tu na ogół nie aprobujemy. Pan Rektor pamięta zapewne, w jakich okolicznościach obalono przed dwoma laty prezesurę Bujaka. Sprawozdanie jego wykazało wielki postęp w rozwoju Towarzystwa - nikt nie miał mu pod względem rzeczowym nic do zarzucenia, ale Bujak okazał się na swoim stanowisku człowiekiem zbyt niezależnym, przy tym bronił słusznej zasady równego udziału w ciężarach Towarzystwa wszystkich oddziałów - i jedynie dlatego musiał ustąpić. Była to gra prof. M. Handelsmana, który niezależnych ludzi nie lubi. [--] Teraz jest możliwość naprawienia tej krzywdy i szkody bez

\footnotetext{
130 W. Konopczyński, „Dziennik”, z. 127, zapis z 4 VI 1935.

131 Ibidem, z. 123, zapis z 24 V 1934.

132 Ibidem, zapis z 25 V 1934.

133 Ibidem, z. 128, zapis z 23 III 1936.

134 „Podobno Dembiński jest warszawskim kandydatem na prezesa PTH”, ibidem,
} zapis z 5 V 1936. 
większych tarć. Jedynym kandydatem Lwowa na prezesa PTH jest Bujak. Zgodził się on po dłuższym oporze kandydować, bo też przerasta naszych kolegów tamtejszych o 1-2 głowy - powinien więc zwyciężyć. Tymczasem jak słyszę, uprojektowano w Warszawie, aby przeciwstawić mu osobę Pana Rektora z tym, żeby po obsadzeniu katedry historii polskiej prezesem został ów następca śp. Zakrzewskiego, który by mógł mieć coś przeciw osobie Pana Rektora i ja pierwszy oddałbym mu swój głos, choćby ze względu na jego wyjątkowy talent przewodniczenia, nie mówiąc o zasłudze naukowej, gdyby Pan był profesorem lwowskim. Ale mówić, że się jest zasadniczo za utrzymaniem zarządu prezesury PTH we Lwowie, a wyszukiwać osobę prezesa na drugim końcu Polski - to nieszczerość podszyta prywatną animozją. Wysunięto kandydaturę Pana Rektora (jeżeli to prawda), aby nią utrącić Bujaka, o którym się głosi, że on przewodniczenia nie przyjmie i aby dla tej gry pozyskać głosy delegatów poznańskich. Nie chciałbym ani w tej korespondencji, ani później na Walnym Zgromadzeniu we Lwowie wnikać głębiej w motywy działania i metody tych czynników, które od szeregu lat starają się prowadzić na pasku nasze Towarzystwo. Ale też ufam, że bez tego się obejdzie. Jestem przekonany, że cała wiadomość o świeżym pomyśle części warszawiaków okaże się przedwczesną ${ }^{135}$.

Dembiński odpisał natychmiast, że nie zamierza kandydować, a prezesem powinien zostać Bujak ${ }^{136}$.

Uradowany dobrą nowiną Konopczyński poinformował o wszystkim Bujaka, podkreślając, że kandydatura Dembińskiego jest pozorna ${ }^{137}$. „A z kłamstwem trzeba walczyć, choćby się miało po stronie prawdy tylko jeden głos większości. Ci Panowie wiedzą, że Dembiński nie przyjmie (statut i ustawa nie pozwalają) - a dążą tylko do udaremnienia wyboru, aby zmienić statut i przenieść zarząd do Warszawy. Z tym musimy walczyć"138.

W obliczu wycofania się z rywalizacji Dembińskiego Handelsman poniechał prób utrącenia kandydatury Bujaka, za jego namową

135 APAN, Oddział w Poznaniu, PIII-34, j.a. 134, List W. Konopczyńskiego do B. Dembińskiego, Kraków, 6 V 1936, k. 43. W podobnym tonie napisał do Dembińskiego Kutrzeba, zob. BO, Przyb. 50/69, rkps, Spuścizna F. Bujaka. Kopia listu S. Kutrzeby do B. Dembińskiego, Poznań, 15 V 1936, k. 483. Zob. też T. Kondracki, Polskie Towarzystwo Historyczne, s. 143.

136 Archiwum Rodziny Konopczyńskich w Gliwicach, List B. Dembińskiego do W. Konopczyńskiego, Poznań, 7 V 1936; „Dembiński odpisał z punktu, że o prezesurze ani myśli. Za to myśli delegaturę w Komitecie Międzynarodowym spuścić Handelsmanowi; to uważam za nieuniknione”, W. Konopczyński, „Dziennik”, z. 128, zapis z 8 V 1936.

137 „Przyszły wiadomości, że właśnie dzisiaj rozstrzyga sprawę Lwów, a jutro Warғ szawa”, W. Konopczyński, „Dziennik”, z. 129, zapis z 11 V 1936.

138 BO, Przyb. 120/58, rkps, List W. Konopczyńskiego do F. Bujaka, Kraków, 11 V 1936. 
„Warszawa postanowiła nie wysyłać delegacji, tylko członków zarządu” na wybory do Lwowa ${ }^{139}$. Natomiast środowisko krakowskie opowiedziało się za lwowskim kandydatem ${ }^{140}$. Kutrzeba uważał, że to dzięki niemu Bujak zostanie prezesem, choć w krakowskim środowisku historycznym utrzymywało się przekonanie, iż to Konopczyński był spiritus movens przedwyborczej akcji ${ }^{141} .20$ maja 1936 r. na posiedzeniu Zarządu Głównego PTH postanowiono jako kandydata na prezesa przedstawić Walnemu Zgromadzeniu Delegatów Bujaka. Lwowski historyk wyraził zgodę, ale zrobił to „ze strasznie nieszczęśliwą miną"142. Następnego dnia delegaci zgodnie wybrali Bujaka, choć Konopczyński do końca nie był pewien jego sukcesu, gdyż „do komisji matki weszli sami antybujakowcy”"143. Jeszcze tego samego dnia odbyło się posiedzenie zarządu, podczas którego powierzono funkcję redaktora „Kwartalnika Historycznego” Modelskiemu, delegata do spraw międzynarodowych Handelsmanowi, skarbnika Urbańskiemu i sekretarza Kazimierzowi Tyszkowskiemu ${ }^{144}$. Kilkanaście dni później w trakcie posiedzenia lwowskich członków Zarządu Głównego PTH postanowiono, w celu odciążenia prezesa, powołać odpowiednich referentów: do spraw administracyjnych - Barwińskiego i Tyszkowskiego, do spraw wydawniczych - Barwińskiego i Modelskiego, do spraw bibliografii Umińskiego i Modelskiego ${ }^{145}$.

Druga kadencja Bujaka trwała rok. Na przeszkodzie stanęła choroba i leczenie szpitalne, jakiemu musiał się poddać. Konopczyński był bardzo zasmucony nie tylko chorobą przyjaciela, ale i chęcią zrzeczenia się przez niego funkcji ${ }^{146}$. Na posiedzeniu Walnego Zgromadzenia Delegatów PTH 5 czerwca 1937 r. Bujak podał się do dymisji, uzasadniając ją w liście do delegatów stanem zdrowia i dziękując tym, którzy podczas trwania

139 W. Konopczyński, „Dziennik”, z. 129, zapis z 16 V 1936.

140 „Wieczorem był zarząd krakowskiego oddziału PTH. Szedł gładko, ospale, a trwał coś trzy godziny. Dąbrowski nieobecny, Kukiel się trochę demaskował. Ustaliliśmy, że prezes musi być ze Lwowa", ibidem, zapis z 7 V 1936.

141 BO, Przyb. 50/69, rkps, List S. Kutrzeby do F. Bujaka, Kraków, 12 V 1936, k. 481.

142 CDIAUL, f. 711, op. 1, spr. 3, Protokół z posiedzenia Zarządu Głównego PTH, Lwów, 20 V 1936. Zob. też W. Konopczyński, „Dziennik”, z. 129, zapis z 20 V 1936 r.

143 APAN, PTH I-3, j.a. 2, Protokół z posiedzenia Walnego Zgromadzenia Delee gatów PTH, Lwów, 21 V 1936. Zob. też W. Konopczyński, „Dziennik”, z. 129, zapis z 21 V 1936.

${ }^{144}$ CDIAUL, f. 711, op. 1, spr. 3, Protokół z posiedzenia Zarządu Głównego PTH, Lwów, 21 V 1936.

145 Ibidem, Protokół z posiedzenia lwowskich członków Zarządu Głównego PTH, Lwów, 8 VI 1936.

146 BO, Przyb. 120/58, rkps, List W. Konopczyńskiego do F. Bujaka, Kraków, 10 II 1937. 
choroby wykonywali jego obowiązki ${ }^{147}$. Po odczytaniu pisma delegaci jednogłośnie wybrali na stanowisko prezesa Kolankowskiego, który od pół roku pracował w Katedrze Historii Polski Uniwersytetu Jana Kazimierza ${ }^{148}$. Nowy prezes sądził, że został wybrany z pewnym ociąganiem się ze strony „bujakowców”. Utwierdziło go w tym przekonaniu przemówienie, jakie wygłosił na cześć ustępującego prezesa Tyszkowski.

Czegóż w nim nie było? Wspaniały rozwój i rozkwit PTH, liczba jego członków, „Kwartalnik Historyczny”, odczyty i referaty, prelegenci, wszystko to tak zadawalało niektórych członków głównego zarządu (np. Tyszkowskiego), wprost im imponowało i upajało, że w odejściu z prezesury prof. Bujaka widzieli bliski upadek, nieomal koniec PTH. Żadnemu z nich nie przyszło na myśl, dlaczego to w ciągu pięćdziesięciu lat istnienia Towarzystwa nie zdobyło się ono choćby na najskromniejszy kąt własny, na jakąś stałą siedzibę, gdzie by można było przynajmniej złożyć akta, protokoły, druki i pomieścić bibliotekę wraz z redakcją „Kwartalnika”? Toteż, widząc ten niemały mankament w życiu tak poważnej instytucji, dałem spokój wszelkim chwalcom pro praeterito oraz prognostykom na przyszłość i podziękowawszy krótko za wybór, zapowiedziałem swe starania o wybudowanie we Lwowie odpowiedniego dla PTH domu - siedziby głównej ${ }^{149}$.

Po dokonanym wyborze odbyły się obchody pięćdziesięciolecia założenia PTH. Uroczystości rozpoczęły się na Cmentarzu Łyczakowskim, gdzie zebrało się około stu historyków. „[Stanisław] Kętrzyński miał niezłe przemówienie na grobie [Ksawerego] Liskego, [Ludwik] Bernacki lepsze tamże nad [Romanem] Pilatem. Potem zwiedziliśmy groby Finkla, A. Semkowicza, W. Kętrzyńskiego, [Ludwika] Kubali, [Oswalda] Balzera, obok którego leży wstrętny mu Zakrzewski”. Na popołudniowym zebraniu zarządu na miejsce krytykowanego Modelskiego wybrano na redaktora „Kwartalnika Historycznego” Tyszkowskiego ${ }^{150}$.

Pod koniec lat trzydziestych Konopczyński ograniczył swoje kontakty z lwowską centralą kierowaną przez nieprzychylnego mu Kolankowskiego. Rzadziej jeździł na posiedzenia Zarządu Głównego PTH, ograniczając się do prac w krakowskim oddziale. Również inni krakowscy historycy zmniejszyli intensywność kontaktów z Lwowem. Większe

147 APAN, PTH I-3, j.a. 2, Protokół z posiedzenia Walnego Zgromadzenia Delegaa tów PTH, Lwów, 5 VI 1937. Szerzej zob. T. Kondracki, Polskie Towarzystwo Historyczne, s. $143-147$.

${ }_{148}$ W. Konopczyński, „Dziennik”, z. 131, zapis z 5 VI 1937.

149 L. Kolankowski, Zapiski pamiętnikarskie, oprac. S. Grochowina, Toruń 2012, s. $244-245$.

150 W. Konopczyński, „Dziennik”, z. 131, zapis z 6 VI 1937. 
zainteresowanie wzbudziła jedynie budowa domu dla Towarzystwa i dyskusja nad dydaktyką nauczania historii w szkołach ${ }^{151}$. Szybkie tempo budowy zaimponowało Konopczyńskiemu, który uważał, że „Kolankowski cudów dokonuje"152.

Pod koniec dwudziestolecia międzywojennego ostre spory w Towarzystwie wzbudzała polityczna postawa Konopczyńskiego. 29 stycznia 1939 r., podczas obchodów dwudziestopięciolecia krakowskiego oddziału PTH, profesor wygłosił referat pt. „Teraźniejszość i przyszłość nauk historycznych w Krakowie". Wykład wywołał masę sprzeciwów wśród zgromadzonych w auli UJ historyków ${ }^{153}$.

Wzburzony odczytem Kętrzyński złożył na ręce prezesa oddziału oficjalny protest ${ }^{154}$. W odpowiedzi Kutrzeba deklarował: „stosunek mój do niego [tj. Konopczyńskiego] jest bardzo dziwny. Ogromnie cenię jego pracę, wprost niezwykłą, zarówno co do jej wydajności, jak i co do wartości coraz większej w stosunku do jego prac dawniejszych. Z drugiej strony jego niesłychanie daleko idące, bardzo swoiste poglądy doprowadzają do tego, że muszę niejednokrotnie wkraczać, by rozmaitego rodzaju wybuchy temperować, a przy tym muszę się liczyć z jedną rzeczą, iż jest to człowiek bardzo ciężko chory. O tym wie tylko dwóch lekarzy i ja, przed którym przypadkowo jeden z lekarzy się niebacznie wygadał, przypuszczając, że te rzeczy ja znam" 155 .

Odpowiedź nie zadowoliła Kętrzyńskiego, który stwierdził, że wystąpienie Konopczyńskiego spotkało się z takim oburzeniem lwowian i warszawian, iż zgodnie oświadczyli, że „w przyszłości nie będą głosować na p. Konopczyńskiego do zarządu PTH. Takie same sygnały dochodziły z mniejszych ośrodków. Pan Konopczyński otrzyma zatem 30-35 głosów na 50. $\mathrm{Z}$ tego trzeba sobie zdawać sprawę i nie narażać starego człowieka na przykrości. Kraków musi jego kandydaturę wycofać i wyznaczyć kogoś, kogo zebranie delegatów łatwiej strawi"156.

Na skutek obiekcji historyków warszawskich Kutrzeba zażądał od Konopczyńskiego skreśleń w jego styczniowym wystąpieniu. Profesor

151 Ibidem, z. 132, zapis z 27 XI 1937.

152 Ibidem, z. 134, zapis z 8 XII 1937.

153 Szerzej zob. B. Tracz, op. cit., s. 82-85. Niestety w papierach rodzinnych nie zachował się maszynopis referatu. O tym więcej zob. P. Biliński, Władysław Konopczyński w polityce II Rzeczypospolitej, DN 2016, 4, s. 33-64.

154 AN PAN i PAU Kr, K III-11, j.a. II/84, List S. Kętrzyńskiego do S. Kutrzeby, Warr szawa, 5 II 1939.

155 Ibidem, Kopia listu S. Kutrzeby do S. Kętrzyńskiego, Kraków, 18 III 1939. Konopp czyński przewlekle chorował na angina pectoris.

${ }^{156}$ Ibidem, List S. Kętrzyńskiego do S. Kutrzeby, Warszawa 21 III 1939. 
„zgodził się tylko na lekki retusz"157. Po zapoznaniu się z jego argumentami „Kutrzeba aż spać nie mógł [--], nie było innej rady, jak ratować prezesowski sen wycofaniem z «Kwartalnika» całej mojej mowy" - konstatował ironicznie Konopczyński ${ }^{158}$. Wycofanie tekstu z redakcji „Kwartalnika Historycznego" nie załatwiło jednak sprawy. Oburzony profesor sądził, że „trzeba będzie chyba zrezygnować z wiceprezesury [krakowskiego oddziału PTH] bo trudno stwarzać precedensy na niekorzyść późniejszych wiceprezesów, żeby twórcy krakowskiego Oddziału kneblowano usta" ${ }^{159}$. W dwa dni później na ręce Feldmana złożył rezygnację z funkcji wiceprezesa ${ }^{160}$, a następnie przesłał informację o swoim wycofaniu się z zarządu krakowskiego oddziału do Tyszkowskiego ${ }^{161}$. Zamierzał także opublikować tekst swojej wycofanej z „Kwartalnika” mowy jubileuszowej w innym periodyku naukowym, nie zgodził się bowiem na poprawki, których domagał się Kutrzeba ${ }^{162}$. Realizacji tego zamierzenia przeszkodził wybuch wojny.

$\mathrm{Na}$ wieść o nieprzychylnej atmosferze panującej w środowisku Konopczyński złożył rezygnację z członkostwa w Zarządzie Głównym $\mathrm{PTH}^{163}$. W liście do Kolankowskiego pisał, że w związku z objęciem obowiązków dziekańskich musi „unikać posiedzeń, sporów, tarć i nie pracować nadmiernie", gdyż źle to wpływa na stan jego nadwyrężonych nerwów. Ponadto informował, że z tych właśnie względów zrezygnował ostatnio z wiceprezesury krakowskiego Oddziału $\mathrm{PTH}^{164}$. Na posiedzeniu 2 czerwca 1939 r. Zarząd Główny PTH przyjął rezygnację Konopczyńskiego i podkreślił jego dotychczasowe zasługi. Profesor zastanawiał się, ,jaką minę miał Kętrzyński”, kiedy prezydium przyjmowało jego rezygnację ${ }^{165}$. Miejsce uczonego w zarządzie zajął Kot ${ }^{166}$. Z listu Kutrzeby do Handelsmana wynika, że animozje wokół autora Konfederacji barskiej nie ucichły po jego rezygnacji i utrzymywały się jeszcze podczas wojny ${ }^{167}$. Wybiegając nieco naprzód, stwierdzić należy,

157 W. Konopczyński, „Dziennik”, z. 135, 136, zapisy z 27 II, 14 IV 1939.

158 Ibidem, z. 136, zapis z 18 IV 1939.

159 Ibidem, zapis z 19 IV 1939.

160 Ibidem, zapis z 21 IV 1939.

161 Ibidem, zapis z 28 V 1939.

162 Ibidem, zapis z 24 IV 1939.

163 Ibidem, zapis z 1 VI 1939.

164 APAN, PTH I-3, j.a. 28, List W. Konopczyńskiego do L. Kolankowskiego, [Kraków, 1 VI 1939], k. 22. Zob. też T. Kondracki, Polskie Towarzystwo Historyczne, s. 147-148.

165 W. Konopczyński, „Dziennik”, z. 136, zapis z 5 VI 1939.

166 Ibidem, zapis z 7 VI 1939.

167 „Staś Kętrzyński pisuje do mnie, z listów jego widzę, że w Warszawie dużo pree tensji do Władzia [Konopczyńskiego]. My go bronimy. Niepotrzebnie się zacietrzewił, 
że konflikty te pogorszyły sytuację uczonego w środowisku historycznym i stały się jedną z przyczyn jego późniejszych prześladowań.

Ogrom pracy Konopczyńskiego w Towarzystwie obrazuje liczba wygłoszonych przez niego odczytów: na 341 wygłoszonych referował 46 razy, drugi w kolejności Semkowicz miał 19 wykładów, a trzeci Grodecki $16^{168}$. Tematyka wystąpień Konopczyńskiego dotyczyła spraw organizacji pracy historycznej (4 referaty), historii powszechnej (4), historii Polski ze szczególnym uwzględnieniem epoki jagiellońskiej (2), monarchii elekcyjnej i upadku Rzeczypospolitej (12), współczesności (2), historii prawa (3), zagadnień ogólnych (4), ocen krytycznych (14) i uroczystych akademii (1). Wśród omawianych przez niego zagadnień dominowały rozbiory krytyczne prac innych historyków, wygłaszane w powołanej z jego inicjatywy Sekcji Krytycznej. Omawiał tam m.in. Historykę Handelsmana, monografię o Stanisławie Auguście Ottona Forsta Battaglii, poezję barską w wydaniu Kazimierza Kolbuszewskiego, rozprawę o stosunku Vergennes'a do Polski Feldmana i wpływ masonów na rozbiory Polski Morawskiego. Jednak głównym polem jego zainteresowań był wiek XVIII, którego dotyczyły odczyty o tajemnicy Michała Jana Paca, marszałka generalności konfederacji barskiej, kampanii Pułaskich na Litwie w 1769 r., pamiętnikarzach konfederacji barskiej i konfederacji barskiej wobec reform ustroju Rzeczypospolitej. Spośród referatów zaliczanych do innych kategorii na szczególną uwagę zasługują prelekcje o idei jagiellońskiej, traktatach międzynarodowych dawnej Rzeczypospolitej, Janie Jakubie Rousseau i Józefie Szujskim. Większość z tych odczytów została ogłoszona drukiem na łamach periodyków naukowych i publicystycznych.

Rodzi się zatem pytanie, dlaczego pomimo ogromnego wpływu, jaki Konopczyński wywierał na krakowskie środowisko historyczne, nie powierzono mu przed 1939 r. stanowiska prezesa krakowskiego oddziału PTH. Według słusznego domysłu Jerzego Maternickiego miała na to wpływ energia i zapędy reformatorskie profesora, budzące opór w stańczykowskim Krakowie. Konkurencję stanowił też Kutrzeba, który miał większe wpływy wśród krakowskich uczonych i dopiero jego śmierć w 1946 r. otworzyła przed autorem Dziejów Polski nowożytnej szansę na prezesurę krakowskiego oddziału ${ }^{169}$.

Działalność Konopczyńskiego w PTH nie była wolna od konfliktów. Ich początek datuje się na rok 1928, kiedy to, jak zostało wspomniane,

niezorientowany jeszcze po długiej niebytności. A na wszystko patrzy tylko ściśle z punktu widzenia naukowego, tak że trudno się z nim dogadać”, AN PAN i PAU Kr, K III-11, j.a. II/78, List S. Kutrzeby do M. Handelsmana, Kraków, 22 I 1942.

${ }^{168}$ J. Feldman, op. cit., s. 201; J. Garbacik, op. cit., s. 199; M. Frančić, op. cit., s. 103.

169 J. Maternicki, op. cit., s. 125. 
stronnicy sanacji wbrew opinii krakowskiego historyka przegłosowali nadanie Piłsudskiemu członkostwa honorowego PTH. Do kolejnego sporu doszło dwa lata później, podczas przygotowań do V Zjazdu Historyków Polskich w Warszawie. Organizatorzy poprosili o patronat nad zjazdem Piłsudskiego, pełniącego wtedy funkcję premiera rządu, co doprowadziło do demonstracyjnego opuszczenia kongresu przez Konopczyńskiego. Z kolei za pierwszej prezesury Bujaka uczony bronił pozycji ośrodka krakowskiego przed hegemonistycznymi zakusami Warszawy.

Konflikt oprócz kwestii politycznych obejmował także sprawy personalne. Można się zastanawiać nad tym, czy spór polegał na relacjach pomiędzy poszczególnymi historykami, czy środowiskami regionalnymi. Na pierwszy rzut oka mogłoby się wydawać, że mamy do czynienia z konfliktem historyków krakowskich z warszawskimi. Jednak materiał źródłowy nie potwierdza tej tezy. Oś konfliktu dotyczyła raczej relacji Konopczyńskiego z Handelsmanem i nie ilustrowała podziałów w łonie całego środowiska, które było bardziej złożone. Należy pamiętać, że Konopczyński spośród historyków warszawskich miał dobre relacje z Adamem Lewakiem, Oskarem Haleckim i Tokarzem, Handelsman zaś sympatyzował z Dąbrowskim i Kutrzebą, który często pełnił rolę mediatora między zwaśnionymi stronami. Podobnie sytuacja wyglądała we Lwowie, gdzie Zakrzewski i jego uczniowie opowiadali się za Handelsmanem, natomiast Bujak, Inglot i Modelski zajmowali opozycyjne stanowisko stosunku do historyka ze stolicy. Jest to kolejny dowód na to, że i w tym wypadku konflikt nie przebiegał według podziałów terytorialnych. Najważniejszym polem sporu, obok personalnego, jak wspominano, były kwestie polityczne dotyczące relacji stronników sanacji z opozycją. Dlatego też po objęciu przez Kolankowskiego prezesury PTH Konopczyński zrezygnował z członkostwa w Zarządzie Głównym i wiceprezesury krakowskiego Oddziału. Do działalności w PTH powrócił dopiero po 1945 r.

\section{Streszczenie}

Autor niniejszego tekstu skoncentrował się na działalności Władysława Konopczyńskiego w Polskim Towarzystwie Historycznym w okresie dwudziestolecia międzywojennego, którą przedstawił w świetle dziennika uczonego i jego listów. Przez cały ten okres Konopczyński był spiritus movens tej organizacji. Potrafił tchnąć życie w skostniały krakowski oddział PTH i zainspirować członków do zbiorowych wysiłków badawczych. Na konferencji w kwietniu 1920 r. zaprezentował program utworzenia ogólnopolskiej organizacji historyków z centralą we Lwowie. Jego pomysłowi środowisko krakowskie pozostało wierne przez cały okres dwudziestolecia międzywojennego. Pomimo rozlicznych inicjatyw i niespożytej energii, jego 
działalność w Towarzystwie nie była wolna od konfliktów. Ich początek datuje się na rok 1928, kiedy to stronnicy sanacji wbrew opinii krakowskiego historyka przegłosowali nadanie Józefowi Piłsudskiemu członkostwa honorowego PTH. Do kolejnego sporu doszło dwa lata później, podczas przygotowań do V Zjazdu Historyków Polskich w Warszawie. Organizatorzy poprosili o patronat nad zjazdem Piłsudskiego, pełniącego wtedy funkcję prezesa rady ministrów, co doprowadziło do demonstracyjnego opuszczenia kongresu przez Konopczyńskiego. Z kolei za pierwszej prezesury Franciszka Bujaka uczony bronił pozycji ośrodka krakowskiego przed hegemonistycznymi zakusami Warszawy. Zrezygnowawszy za szefostwa Ludwika Kolankowskiego z członkostwa w Zarządzie Głównym i wiceprezesury krakowskiego oddziału, do działalności w Towarzystwie Konopczyński powrócił dopiero po $1945 \mathrm{r}$.

\section{Władysław Konopczyński’s Activity in the Polish Historical Society (1913-1939)}

The author focused on the activity of Władysław Konopczyński for the Polish Historical Society in the interwar years, presented in the light of the scholar's diary and letters. Throughout all the interwar period the historian was the spiritus movens of the Society, and was able to breathe new life into the fossilized Cracow branch of the PHS and inspire its members to a collective research effort. At a conference in April 1920 he presented a programme for the formation of a Poland-wide organisation for historians with its centre in Lvov. The Cracow community of scholars remained loyal to his idea throughout the whole interwar period. Despite his numerous initiatives and indefatigable energy, Konopczyński's activity in the Society was not without tensions and conflicts. Their beginning dates to 1928 when supporters of the Sanacja regime, against the historian's will, voted for an honorary membership to the PHS for Józef Piłsudski. Two years later, another controversy erupted during the preparations for the Fifth Convention of Polish Historians in Warsaw. The organisers invited Piłsudski, at that time Chairman of the Council of Ministers, to take the patronage of the convention, and this provoked Kopczyński to ostentatiously leave the congress session. Next, under the first presidency of Franciszek Bujak, the historian defended the position of the Cracow branch against hegemonic designs of Warsaw. And it was not until 1945 that Konopczyński, who under the presidency of Ludwik Kolankowski resigned from the General Board and vice-presidency of the Cracow branch, resumed his activities in the Society.

Translated by Grażyna Waluga

\section{Bibliografia}

Barwiński Eugeniusz, Towarzystwo Historyczne 1901-1914, KH 51, 1937, 1-2, s. 19-40. Biliński Piotr, Władysław Konopczyński w polityce II Rzeczypospolitej, DN 2016, 4, s. 33-64. 
Biliński Piotr, Władysława Konopczyńskiego „boje” o kształt Polskiego słownika biograficznego w latach 1928-1939, „Klio Polska. Studia i materiały z dziejów historiografii polskiej", t. 7, 2015, red. Andrzej Wierzbicki, s. 107-141.

Feldman Józef, Ćwierćwiecze działalności krakowskiego Oddziału Polskiego Towarzystwa Historycznego, KH 53, 1939, 1, s. 196-203.

Frančić Mirosław, Polskie Towarzystwo Historyczne w Krakowie w latach 1913-1939, w: Polskie Towarzystwo Historyczne 1886-1986. Zbiór studiów i materiałów, red. Stefan K. Kuczyński, Ossolineum, Wrocław 1990, s. 97-110.

Garbacik Józef, Oddział krakowski (1913-1956), w: Polskie Towarzystwo Historyczne, 18861956. Księga pamiątkowa z okazji zjazdu jubileuszowego Polskiego Towarzystwa Historycznego w Warszawie 19-21 X 1956 roku, red. Stanisław Herbst, Irena Pietrzak-Pawłowska, Państwowe Wydawnictwo Naukowe, Warszawa 1958, s. 193-200.

Kolankowski Ludwik, Zapiski pamiętnikarskie, oprac. Sylwia Grochowina, Wydawnictwo Uniwersytetu Mikołaja Kopernika, Toruń 2012.

Kondracki Tadeusz, Polskie Towarzystwo Historyczne w latach 1918-1939, Wydawnictwo Naukowe Grado, Torun 2006.

Kondracki Tadeusz, Z myślą o przeszłości polskiej nauki historycznej (konferencja warszawska 11-12 IV 1920 r.), „Teki Historyczne” 21, 1994-1995, s. 141-151.

Konopczyński Władysław, Dziennik 1918-1921, cz. 1-2, wstęp Piotr Biliński, oprac. Piotr Biliński, Paweł Plichta, Muzeum Historii Polski, Ośrodek Myśli Politycznej, Warszawa-Kraków 2016.

Maternicki Jerzy, Władysław Konopczyński, jego miejsce i rola w życiu krakowskiego środowiska historycznego w latach 1918-1939, „Przegląd Humanistyczny” 29, 1985, 3-4, s. 91-125.

Modelski Teofil Emil, Towarzystwo Historyczne 1914-1924, KH 51, 1937, 1-2, s. 41-88. Papée Fryderyk, Słowo wstępne, KH 53, 1939, 1, s. 194-196.

Rutkowski Tadeusz P., Polskie Towarzystwo Historyczne w latach 1945-1958. Zarys dziejów, Adam Marszałek, Toruń 2009.

Sierżęga Paweł, Kazimierz Tyszkowski (1894-1940). Z dziejów nauki polskiej w międzywojennym Lwowie, Wydawnictwo Uniwersytetu Rzeszowskiego, Rzeszów 2011.

Tracz Bogusław, Krakowski Oddział Polskiego Towarzystwa Historycznego i jego członkowie 1913-1945, Księgarnia Akademicka, Kraków 2013.

Tyszkowski Kazimierz, Polskie Towarzystwo Historyczne 1925-1936, KH 51, 1937, 1-2, s. 89-137.

Artykuł powstał dzięki wsparciu NCN (grant nr 2014/15/B/HS3/02223).

Biogram: Piotr Biliński - dr hab., profesor nadzwyczajny Uniwersytetu Jagiellońskiego, kierownik Zakładu Historii Kulturowej w Instytucie Studiów Międzykulturowych UJ. Jego zainteresowania naukowe koncentrują się wokół polskiej historiografii XIX i pierwszej połowy XX w. Podejmuje także zagadnienia z zakresu biografistyki, nauki i kultury. Autor biografii Władysława Konopczyńskiego, Feliksa Konecznego i Stanisława Kutrzeby, a także monografii roku Moszyńskich. Członek Polskiego Towarzystwa Historycznego i Towarzystwa Historiograficznego; kontakt: p_bilinski@wp.pl. 